\title{
MEMBANGUN POLA KOMUNIKASI DAKWAH SEBAGAI ALTERNATIF MENCEGAH SIKAP INTOLERANSI BERAGAMA
}

\author{
Burhanuddin \\ FIDKOM UIN Syarif Hidayatullah Jakarta \\ burhanuddin_dj@yahoo.com
}

\begin{abstract}
Abstrak:
Kegiatan dakwah, merupakan bentuk dari komunikasi karena di dalamnya ada penyampai pesan (da'i) dan penerima pesan (mad'u). Dakwah sebagai proses komunikasi membutuhkan upaya-upaya yang harus didesain secara strategis sebagaimana sebuah komunikasi yang efektif yang mempertimbangkan efek dari komunikan. Berhasil tidaknya kegiatan dakwah tidak terlepas dari bagaimana proses komunikasi antarpelaku dakwah (da'i dan mad'u) berlangsung. Jadi, disinilah kontribusi komunikasi menjadi hal penting yang harus dipertimbangkan dalam kegiatan dakwah. Artinya, secara teoritis, teori-teori komunikasi sebagai sebuah ilmu akan memberikan kontribusi dalam merancang kegiatan dakwah yang efektif, sehingga pesan-pesan islam yang menjadi isi materi dakwah dapat tersampaikan dan berefek pada perubahan sikap mad'u ke arah yang lebih baik sesuai tujuan kehidupan Islam, bahagia dunia akherat.

Membangun pola komunikasi dakwah yang baik dapat mencegah terjadinya konflik-konflik keagamaan di masyarakat. Pesan dakwah yang menyampaikan nilai ketuhanan sejatinya harus dipahami sebagai perwujudan nilai-nilai toleransi, persaudaraan, dan sebagai wujud dialog internal umat beragama serta sebagai upaya membangun kesadaran demi terciptanya kerukunan antarumat beragama. Membangun nuansa harmonisasi merupakan harapan terhadap negara yang majemuk namun untuk merealisasikannya tentu memerlukan suatu upaya dan pola komunikasi yang efektif.
\end{abstract}

Abstract: Da'wah as an activity, is a form of communication because there are messengers (da'i) and recipients (mad'u). Da'wah as a communication process requires efforts that must be strategically designed as an effective communication that takes the effects of the communicant. Success or failure of the da'wah activities cannot be separated from how the communication process between da'i (da'i and mad'u) took place. So, this is where the contribution of communication becomes an important thing to be considered in the activities of da'wah. That is, theoretically, communication theories as a science will contribute in designing an effective da'wah activities, so that Islamic messages into the content of da'wah material can be conveyed and effect on changes in attitude of mad'u to a better direction according to the purpose of life in Islam, life blissfully in this world until akherat.

The true meaning of divinity must be understood as the embodiment of the values of tolerance, brotherhood, and as a form of internal dialogue of religious people as an effort to build awareness for the creation of harmony among religious followers. Building harmonious nuances is the hope of a plural country but to realize it would require an effort and an effective pattern of communication.

Keywords: da'wa communication, alternative, pluralism, tasamuh and religious intolerance 


\section{إنشاء نمط الاتصالات الدعوية في كونه بديلا في وقاية حدوث عدم التسامح في الدين}

Burhanuddin

التمهيد

التسامح أو السماحة كلمة عربية تدل على عدة معان، منها : الجودح، وسعة

الصدر، والتساهل. ويتطير هذا المعنى إلى السلوك يتضمن سعة الصدر على وجود الخلاف الناتج من الشخصية الكريمة. وهذه الكلمة تختلف كثيراً معناها عن كلمة "tolerance" من حيث المعنى، لأنه يصدر من الجود والكرام والإخلاص. 1.

بيّن ابن الحجر في كتاب فتح الباري في شرح صحيح البخاري أن معنى السمحة هو السهلة، حين شرح الكلمات من الحديث النبوي : أحب الدين إلى الله الحنفية السمحة.22 وقال به أحمد بن فارس في كتابه المعجم المقايس اللغة، حيث قال أن السماحة يقصد بها السهولة. 3

وذُكر في القاموس الكبير للغة الإندونيسية أن كلمة التسامح يعني صفة السمحة، أي : سعة الصدر في قبول الغير الذي خالفه في الرأي، والنظر، والاعتقاد، والعادة، والموقف وغيرها. و"toleransi" كلمة دخيلة من اللغة الإبحليزية "tolerance" أي

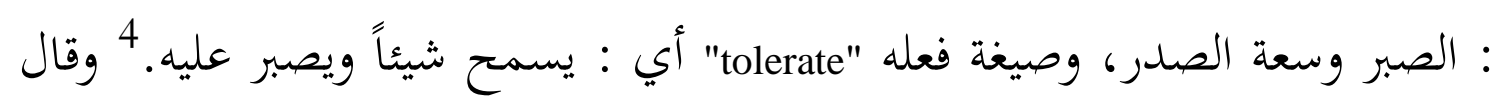


هوربي أس أن كلمة "toleransi" من اللغة اللاتينية "tolerantia" أي : السهولة، والرفق، والحفة، والصبر. 5 وهذا الخلاف في المعنى يؤثر كثيراً في فهم هذه الكلمة واستعمالاتحا في اللغة العربية والإنحلزية.

وفهمنا عن التسامح لا يقوم بنفسه، إذ التسامح له علاقة وثيقة بالتعددية أو الإية.

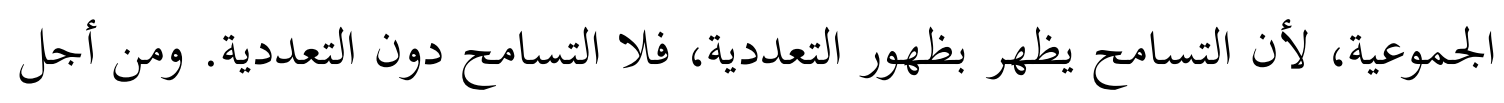
ذلك، فهمنا لحقيقة التسامح يسبقه فهمنا حقيقة التعددية أو الجموعية.

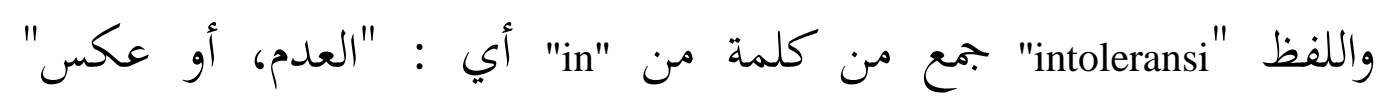

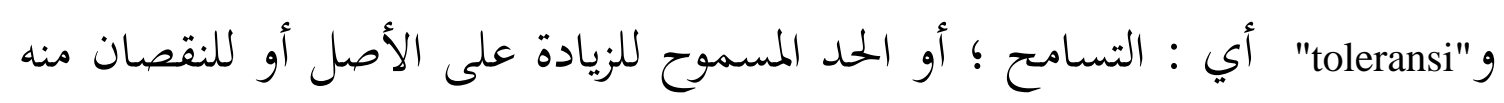

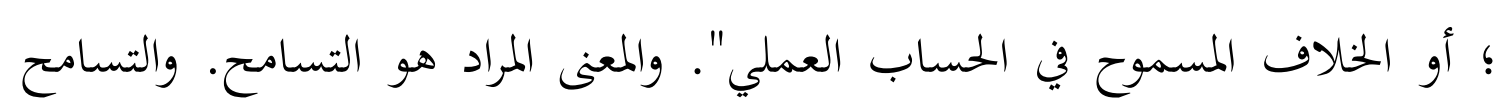

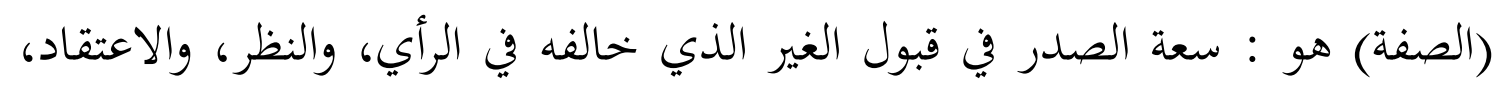
والعادة، والموقف وغيرها.

ومعنى عدم التسامح في الدين في القاموس الكبير للغة الإندونيسية هو : صفة ألفأ من الفرقة من الفرق (سواء أ كان بحتمعاً أو الفرق الدينية أو الفرق غير الدئ الدينية)

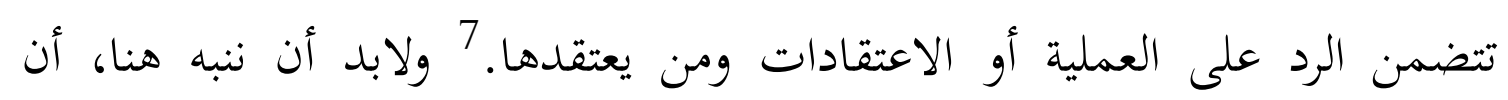
الاعتقاد على صحة الدين التي يدين به أحد وبطلان دين غيره بناء على اعتقاده لم الم المان

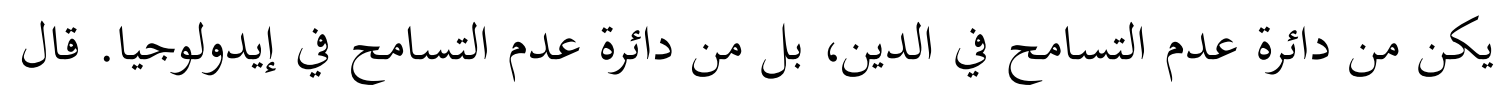

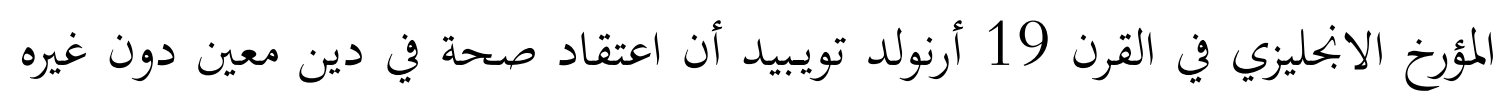
يفسده ويفسد شرعيته.

عدم التسامح تصدر من الغلو في الفكر والنظر، أي : أن عدم التسامح من

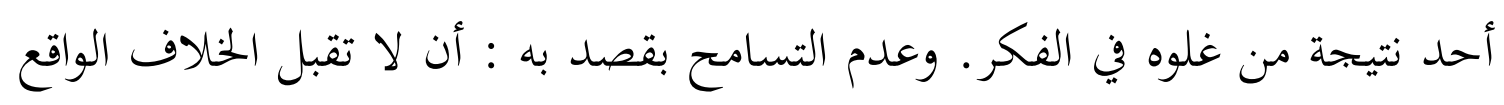
بينك وبين غيرك. والتسامح خلاف ذلك، أي : أت تقبل الخلاف الواقع بينك وبين

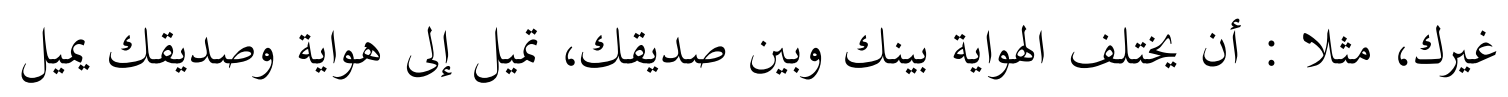


إلى هواية أخرى، فإن تقبل هذا الخلاف الواقع بينك وبين صديقك فهذا التسامح،

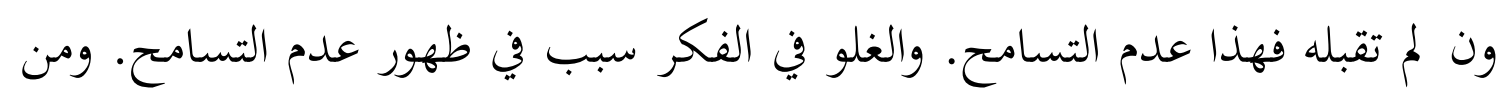

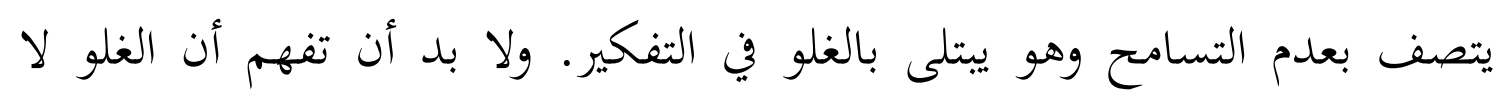

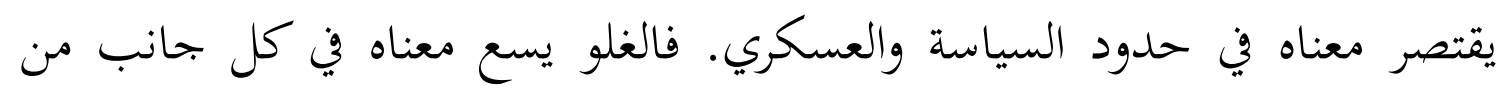

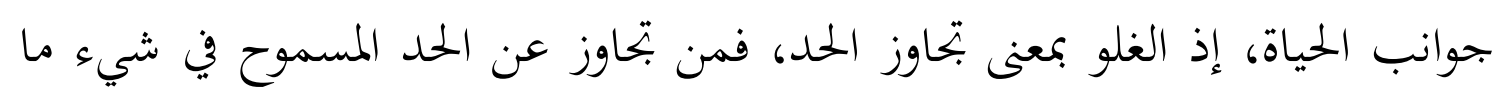

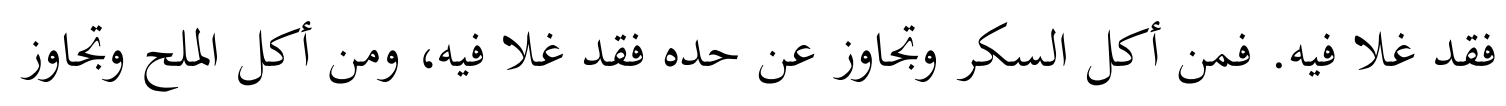

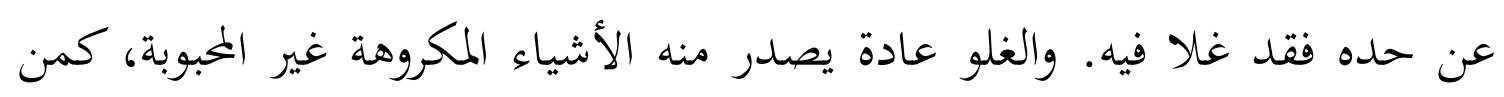

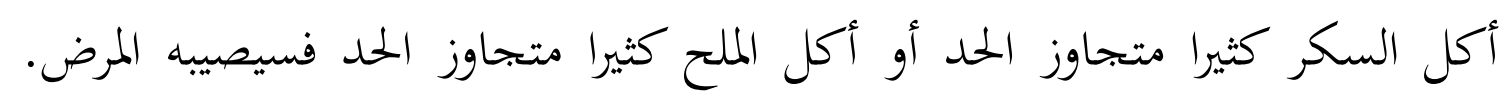
فالغلو لا يقتصر معناه في الأمور الدينية بل يتجاوز غيره من المعاو المعاني. عوامل ظهور عدم التسامح عوامل ظهور التسامح يختلف عن عوامل ظهور الغلو، إذ قد لا يغلو أحد في

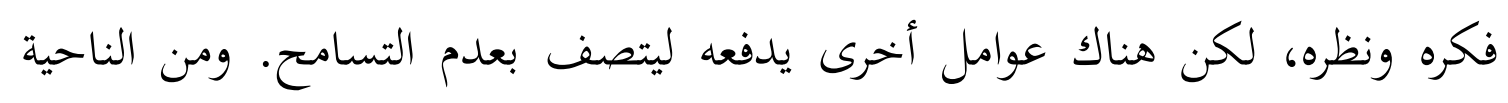

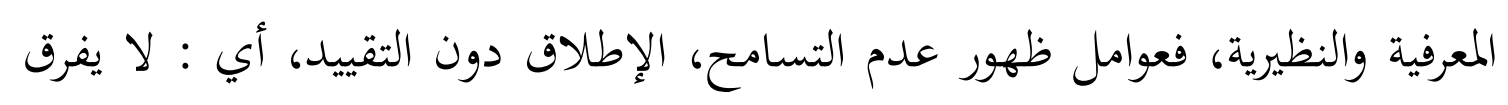

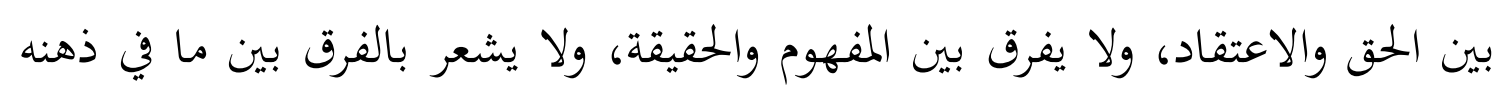
وما في خارجها من الحقيقة الموجودة حوله، وهذا كله العوامل من الناحية المعرفية.

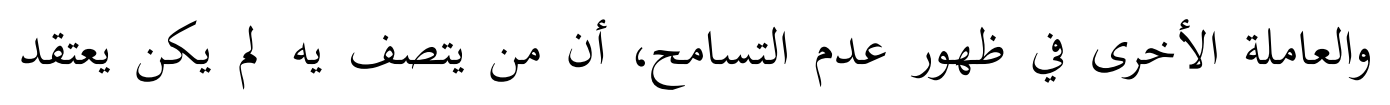

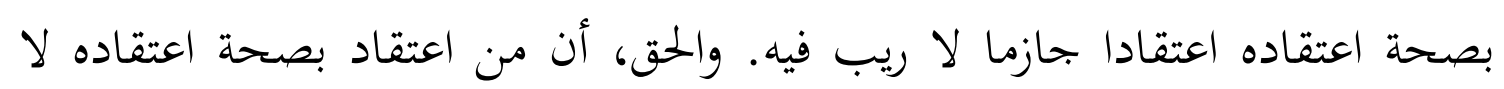

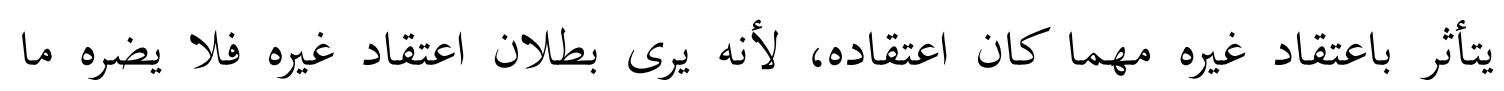

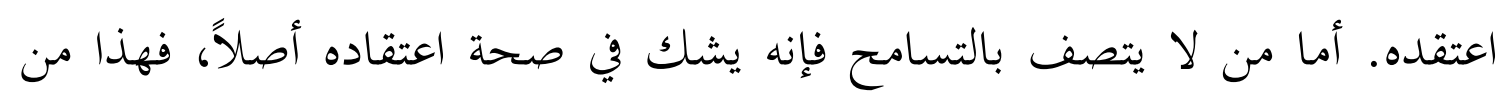
أحد التحاليل في عاملة ظهور عدم التسامح. 9

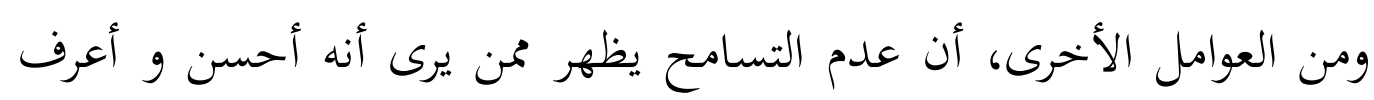

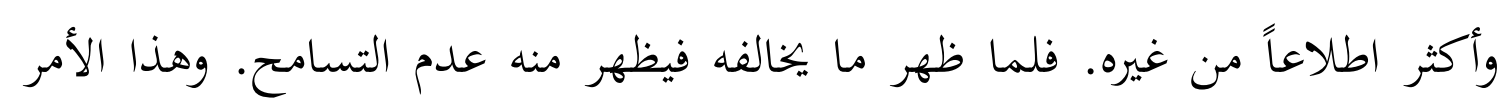


عادة متعلق بالملك والسلطة، لأنه يظن أن من أظهر الخلاف في ملكه وسلطانه

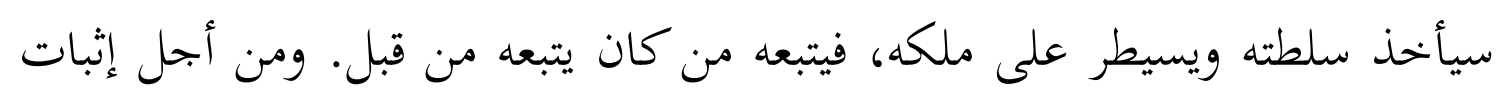

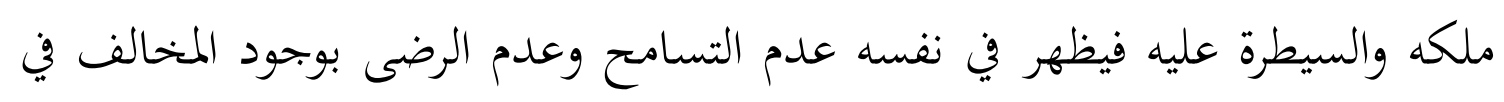
ملكه.

ومن التحليلات الأخرى، أن الخلاف الذي يظهر متأخراً سيفسد ما قد بناه

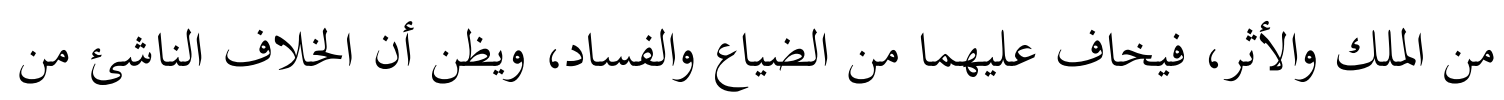

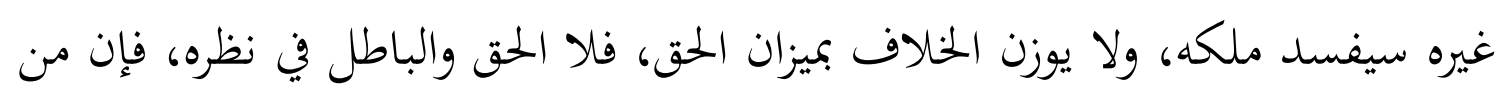
أراد. بهدم ملك ولو كان صحيحاً فلا يكون صحيحاً عنده أبداً.

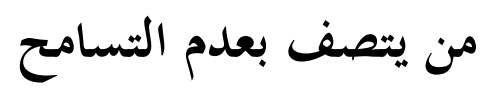

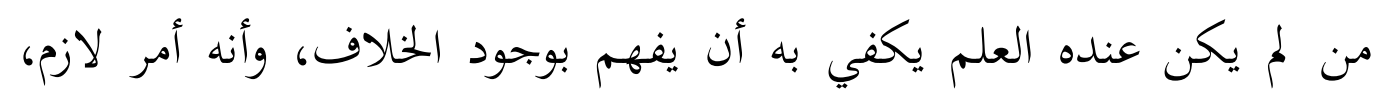

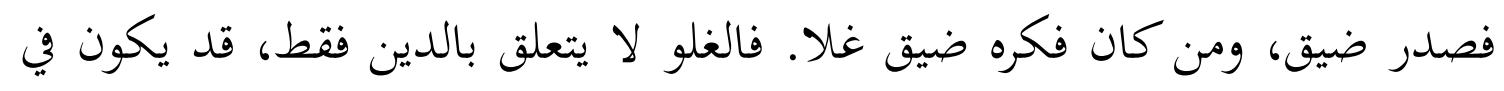

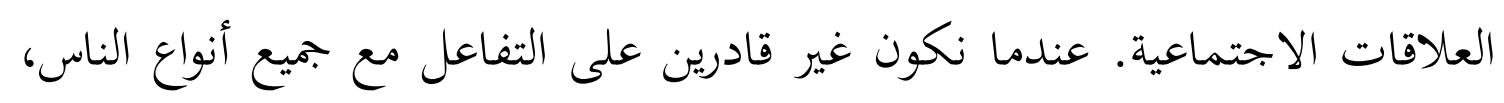
فنحن لسنا متسامحاً. إننا بجد الناس تختلف مستوياقم تعليماً وفهماً، ولكن علينا أن نعاملهم معاملة

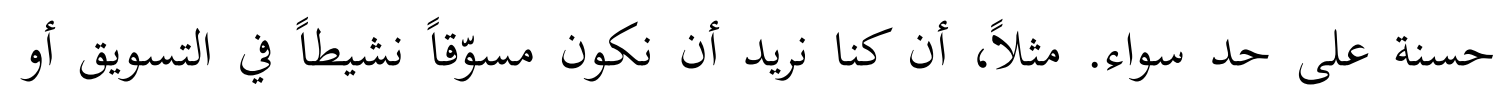

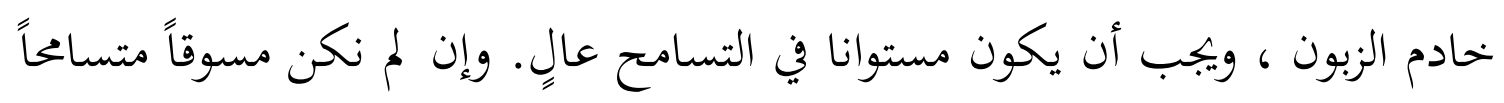
سيصعب علينا إضافة الزبون ، بل قد يتركنا الزبون السابق.

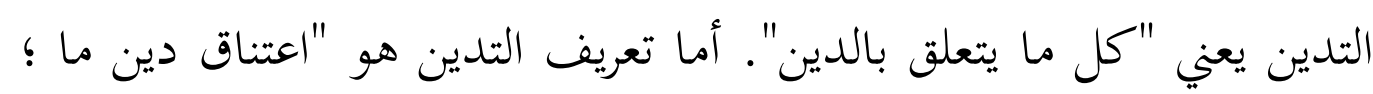

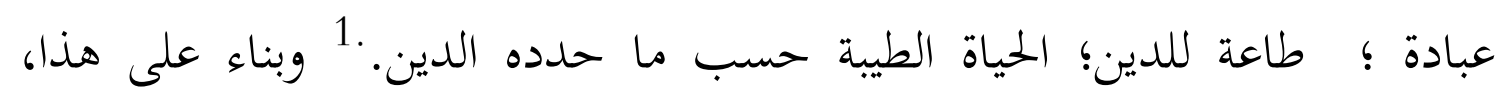

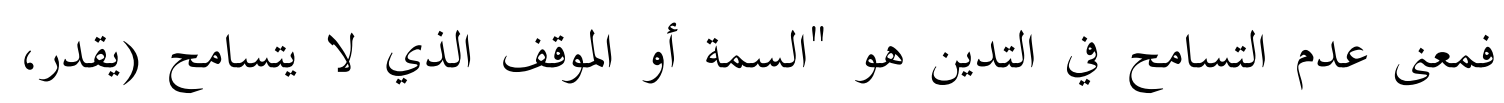
يسمح) بالخلاف الواقع بينه بين غيره في الاعتقادات والأديان. 
وفي بلدنا إندونيسيا، كان سكانها يختلف اعتقاد بعضهم عن بعضٍ. وهذا الأمر تعتبر من ثورة البلد، إذ سكان إندونيسيا مع اختلافهم في الاعتقادات والأديان

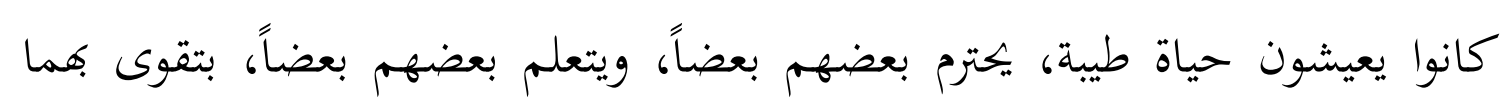

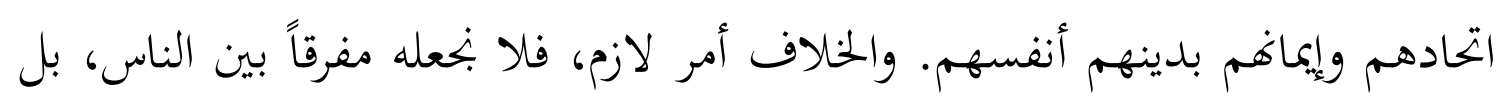

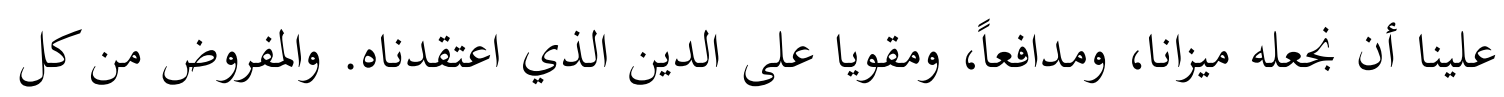

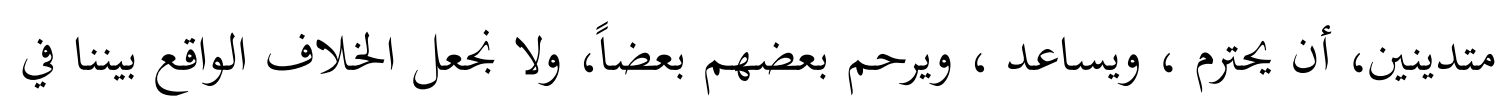
الاعتقاد سببا في المنازعات والمخخاصمات.

هناك فرقتان من الطوائف الدينية في بجتمع متعدد الثقافات، هما البحتمع الديني

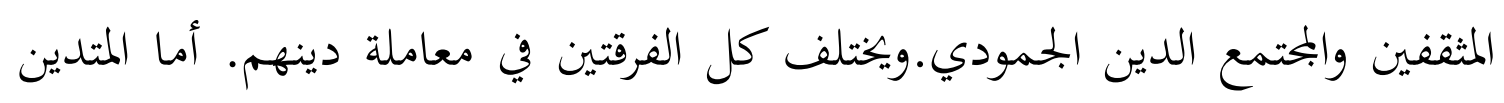

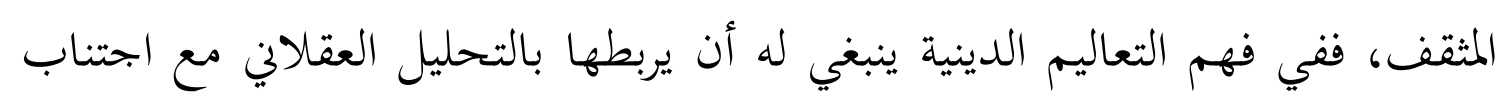

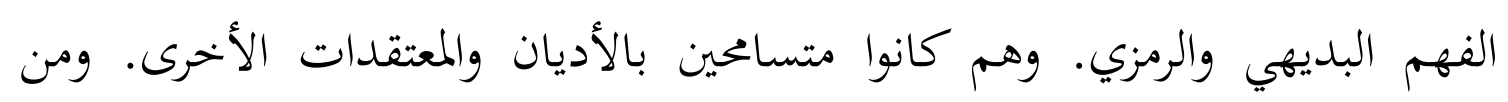

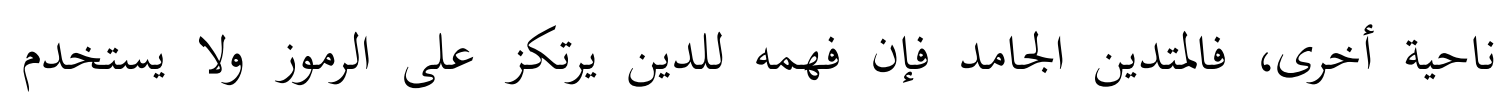

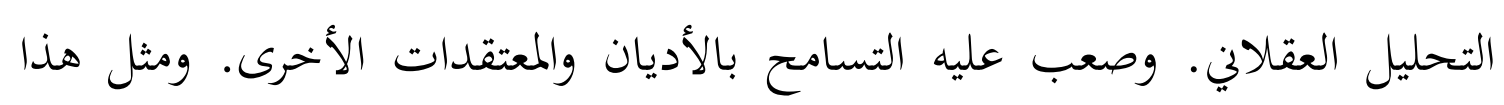

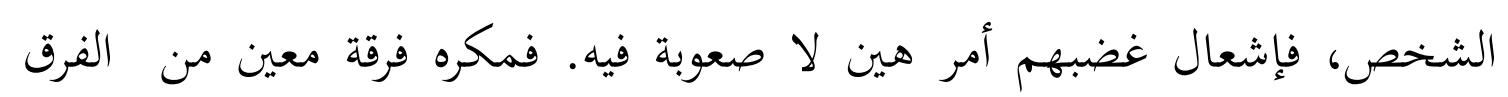
السياسية أو الفرق الاجتماعية. 11

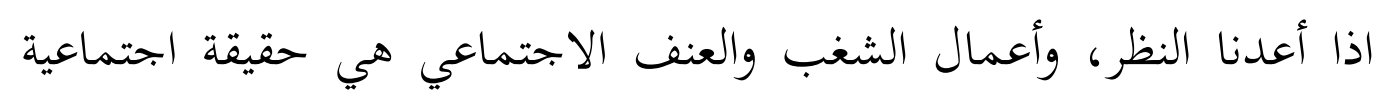

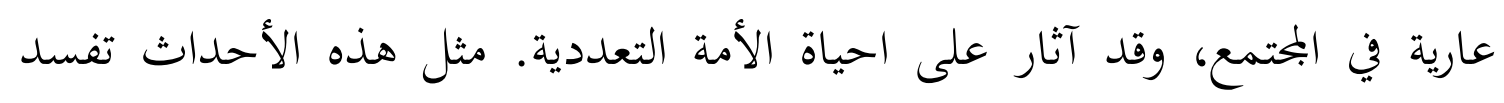

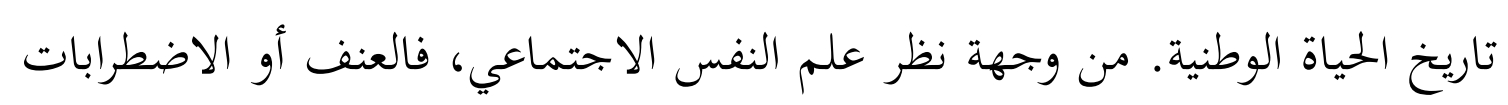

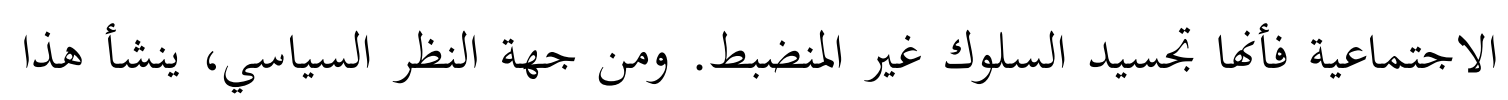

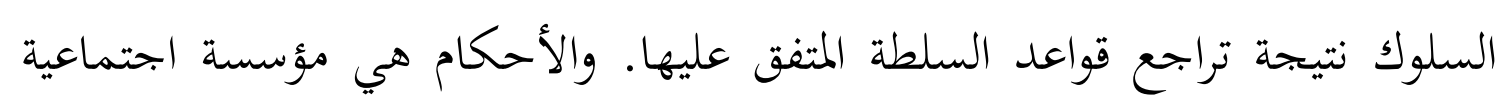

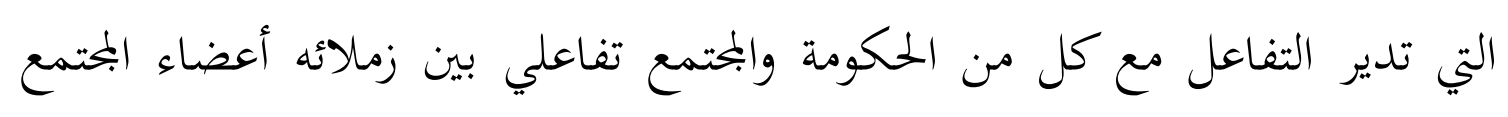


نفسه. في دوامة من العنف أو اجتماعية بتاريخ 9 مايو 2012 في LKiS، إلا ${ }^{12}$.SARA إنشارات تصف كحالة فئ دوالة

والعنف باسم الدين الذي يقع في يوجياكارتا، وخاصة العنف الواقع من قبل

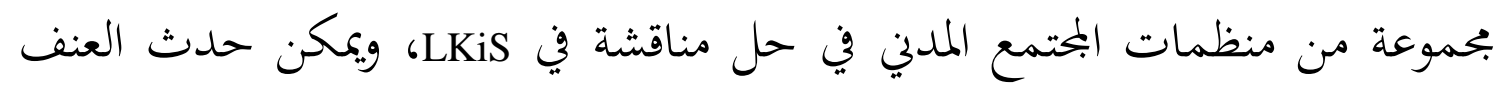

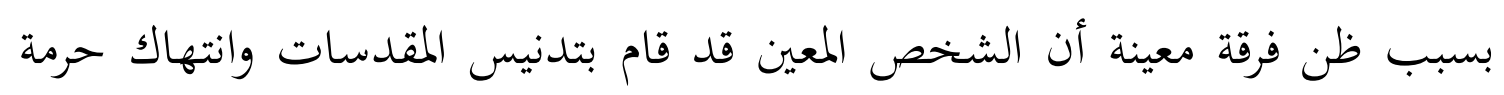

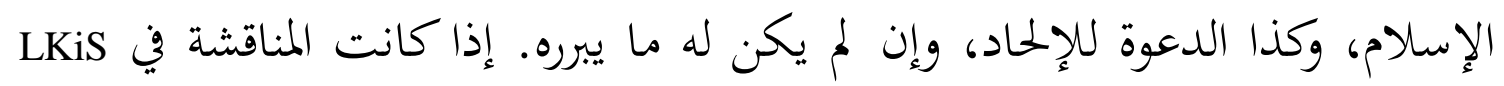

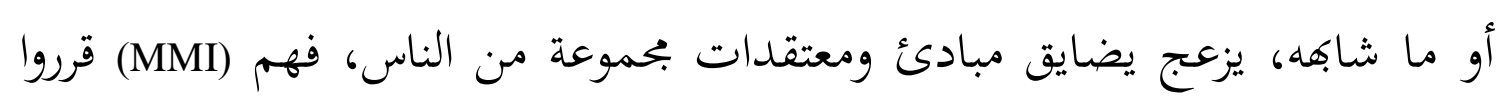

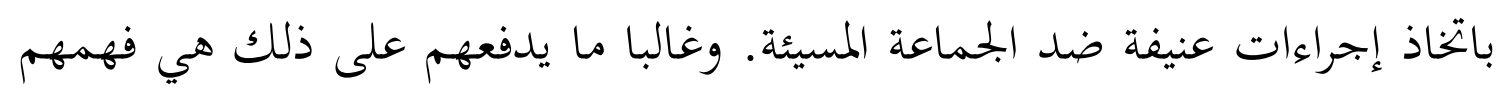

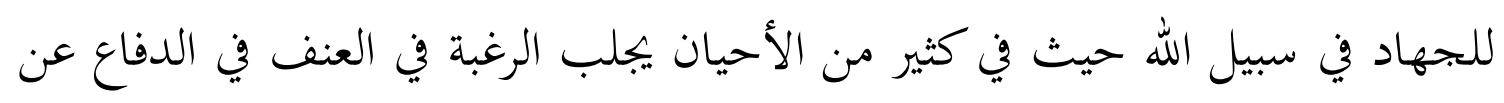

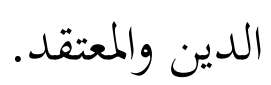

وما وقع في تليكارا كان بسبب عدم التسامحح. ويجب علينا معالجة هذه

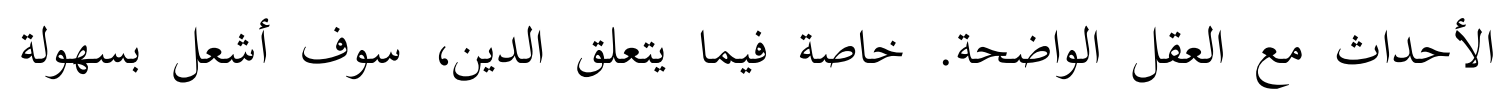

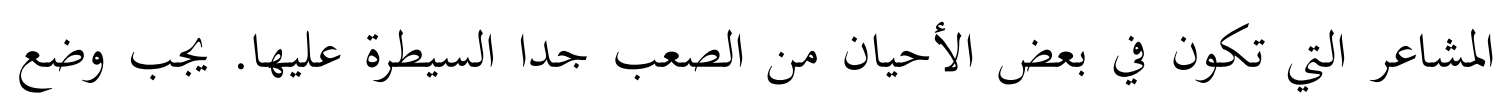

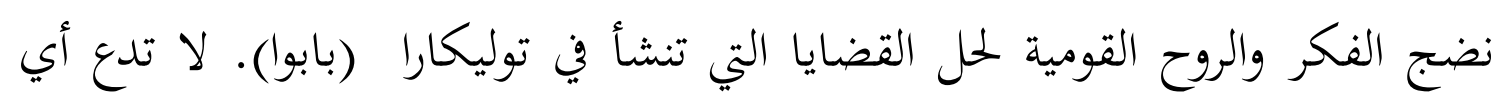

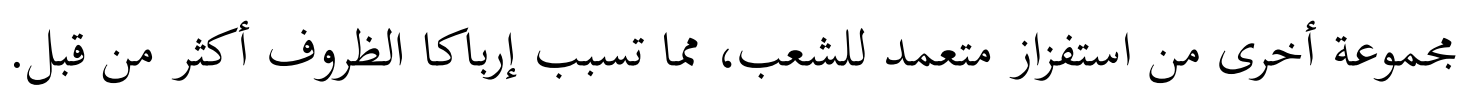

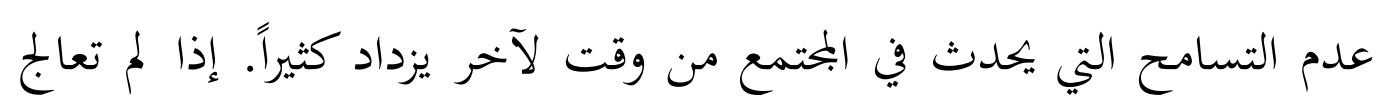

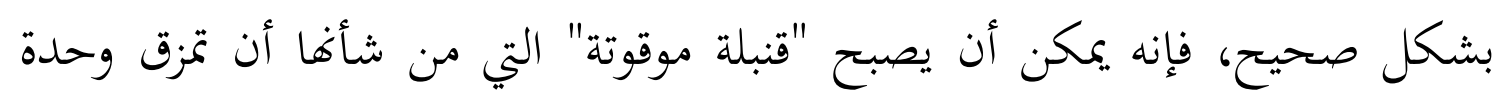

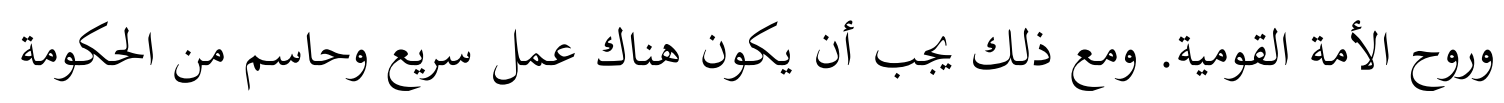

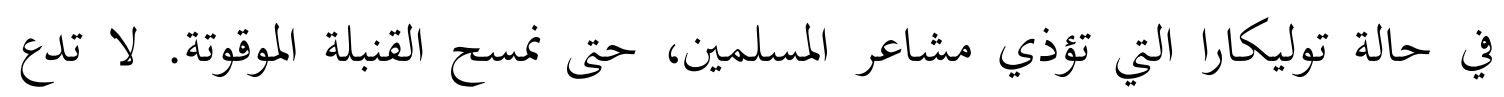
توليكارا في حالة قد تثير فعلا على ظهور حركات من شأها الأفساد.

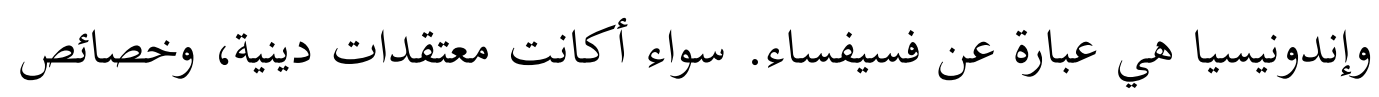
ثنافية، وهوية عرقية، وأنماط أصلية والذوق والتعبير في اللغة والتراث التاريخي، 
وبحموعات الاختيار، الانتماء السياسي، لرؤية الشخصيات وغيرها. عادة فسيفساء، إذا كنت تعتقد للحظة واحدة، داخل اندونيسيا ينعكس أي وقت مضى ما تحدث الأنثروبولوجيا الفرنسي كلود ليفي شتراوس (1995)، التي تقول إن التنوع في الظهر، في الجبهة، وحتى من حولنا. وهكذا، والتنوع في إندونيسيا في نواح كثيرة هو حقيقة واقعة، على الإطلاق ليس جديدا. بسم التنوع، واندونيسيا هي في الواقع حديقة رائعة الجمال، لذلك داخله مليء ديناميات وتحديات. 13

\section{تعريف الاتصتلات الدعوية}

قال لكولن شيري، استنادا إلى فج اجتماعي تعرَّف الاتصالات على أها

محاولة لخلق وحدة اجتماعية باستخدام اللغة، أو توقع لديها في بحموعتها الخاصة من القواعد لمختلف والأنشطة لتحقيق الهدف، والاتصالات هو الحدث الاجتماعي الذي يهدف إلى توفير المعلومات، وترفيهه، التأثير على الآخرين بها. 14 وأوصل كولن شيري، الدعوة الواقع في حد ذاته هو التواصل، والدعوة دون الاتصال لا تكون قادرة على السير نحو الأهداف المرجوة، هذه الرسائل دون التبشير سوف تفقد القيم الإلهية في الحياة. لذلك، من التعاريف للدعوة هو أن مهمتها هي عملية الاتصال الفعال والمستمر، والعامة، والعقلانية، وذلك باستخدام وسائل علمية ووسائل فعالة، في تحقيق المدف. 15 الدعوة هي وظيفة من إيصال رسالة الإسلام للبشرية. في أكثر عملية، المهمة يروج أو يشجع الناس على جهة صياغة هائية التي يمكن اتخاذها من القرآن ولحديث، أو التي صاغها الداعي، وفقا لنطاق رسالته. موجهة الدعوة إلى الرجال، في حين تلقى الرجال ليس فقط الأذنين والعينين ولكن كائنات بلا روح، الذي يفكر ويشعر، التي يمكن أن تحصل ويمكن أن يرفض وفقا للتصور الدعوة. العلاقة عملية الاتصالات مع التراسل الانتشار 
في الإسلام، إن الاتصالات تحت ضغط قوي بما فيه الكفاية بالنسبة للبشر

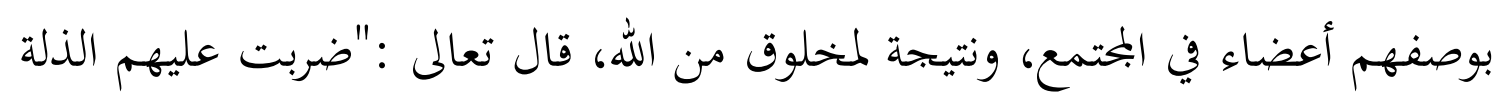

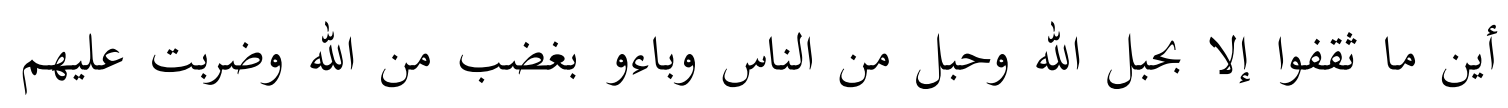

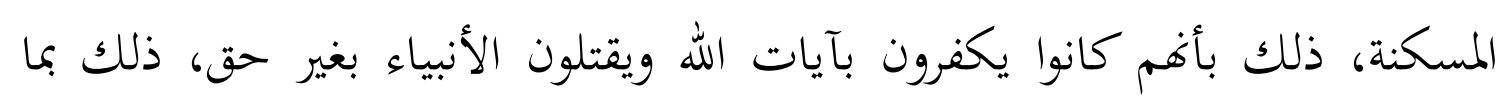
عصوا وكانوا يعتدون.

وفي التفاعل بين الداعي والمددعو، يمكن أن الدعاة ينقل رسائل الدعوة (مواد

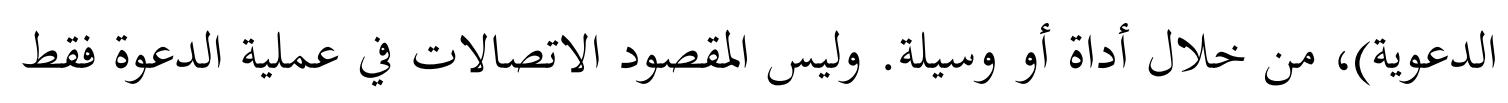

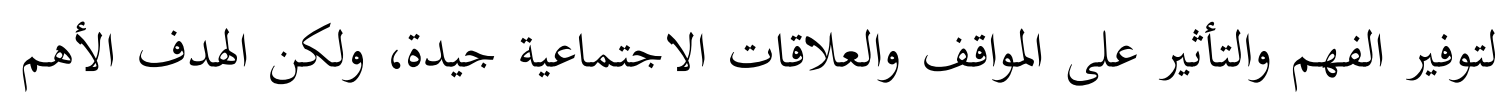

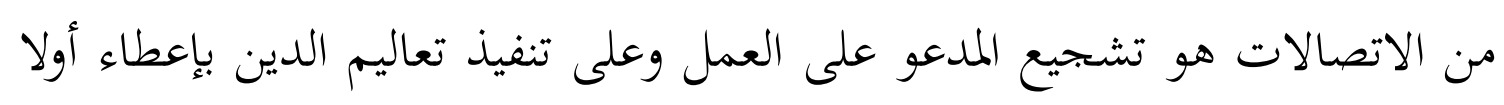
المفاهيم، والتأثير على المواقف، وتعزيز علاقة جيدة.

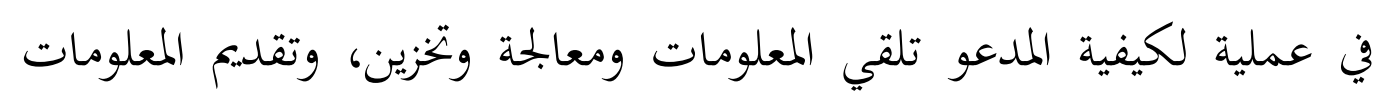

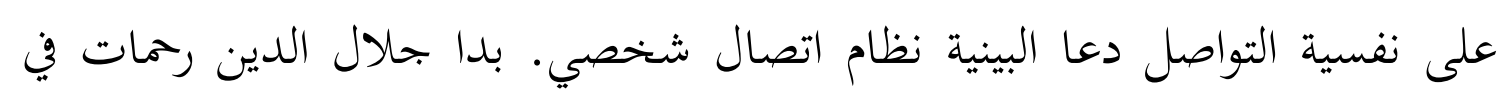

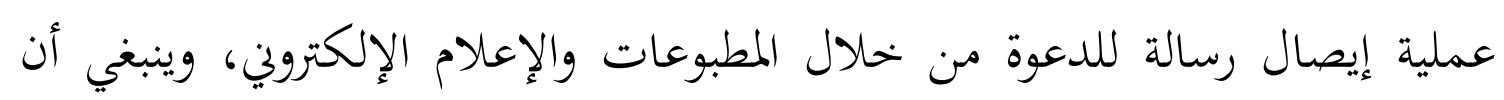

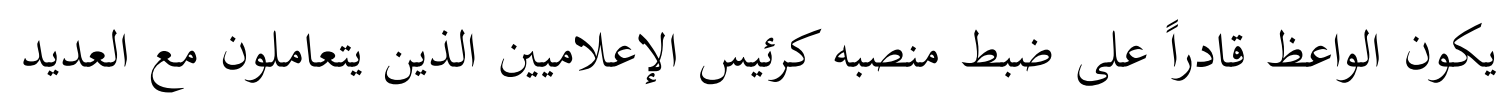
من الجماهير والخلفيات التعليمية والأعمار والمهن المختلفة.

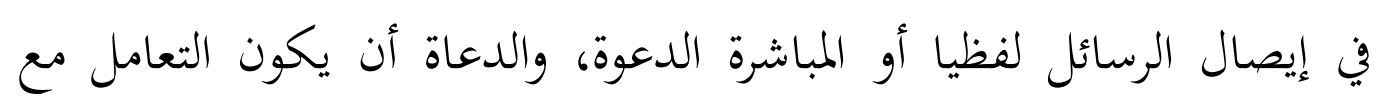
فئات الجمهور التي لها نفس الاتحاه. بحيث يمكن عرض الدعاة الديات تسليم الرسالة الدعائية

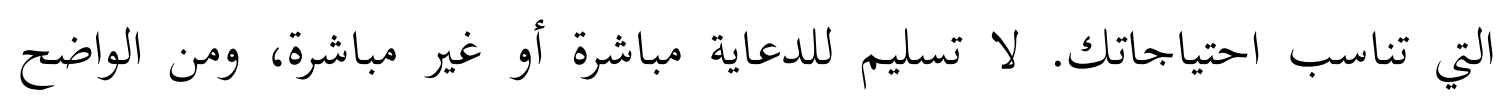

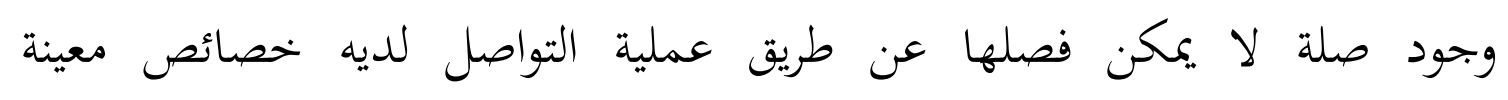

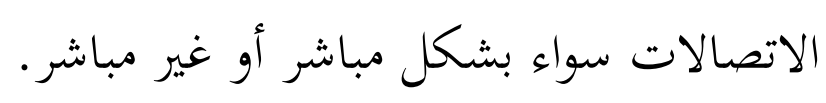
الهدف من الاتصالات الدعوية 
والهدف من أهداف دعاوية أو الاتصال مشتركان والاتصال والدعوة لها هدف

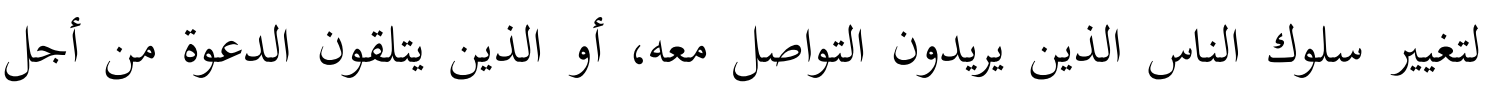

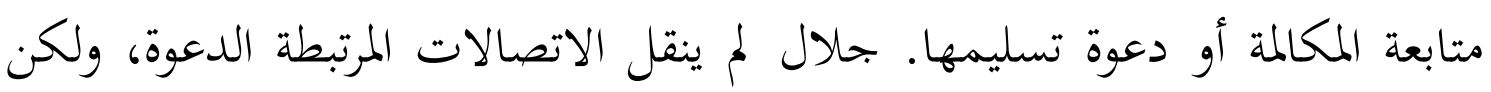

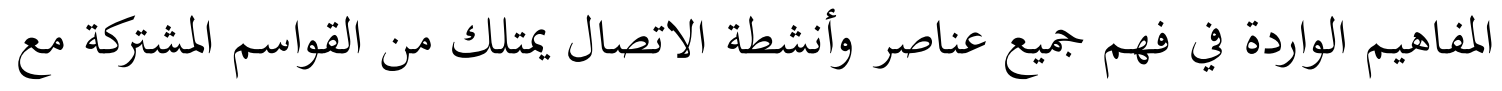

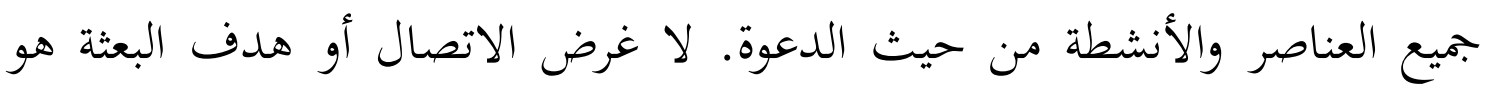

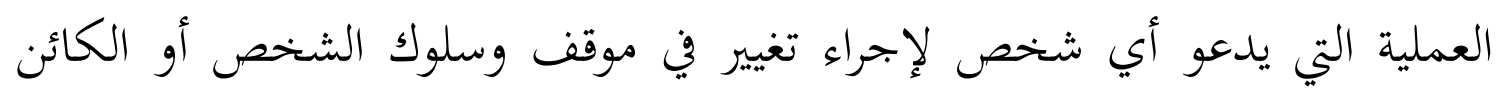
الاتصالات أو الدعوة لتوقعات الجلاني.

الأهداف المراد تحقيقها من الاتصالات من الدعوة نفسها لديها ثلاثة أبعاد.

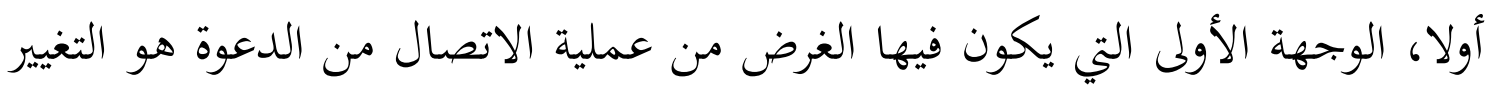

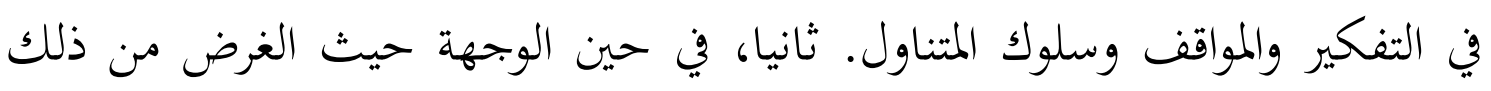

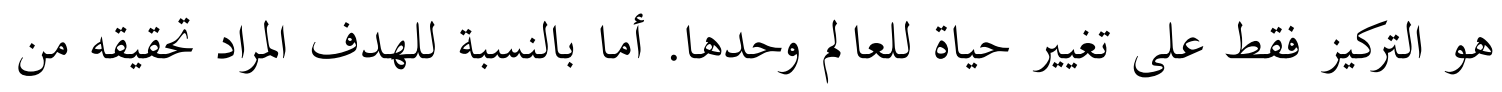

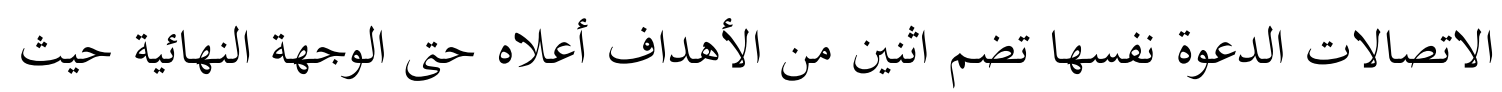
سعادقم في الدنيا والآخرة. أهمية الاتصالات والدعوة

واستنادا إلى قول الله تعالى في سورة النحل الآية 125 أن هناك ثلاثة أساليب

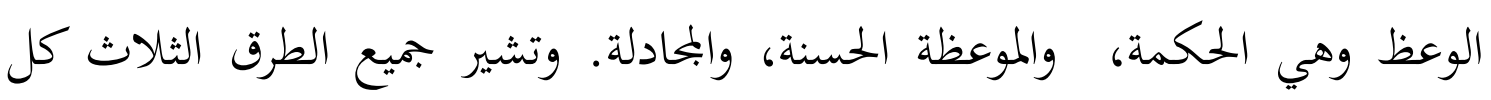

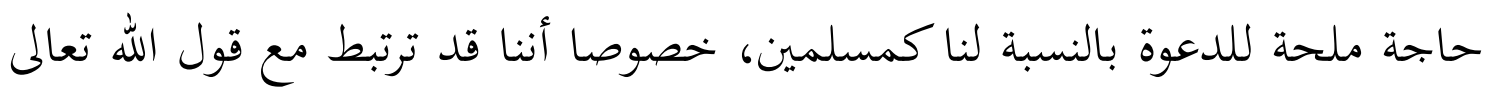
في سورة آل عمران الآية 104. وهذه الآيات تدل على الحاجة الملحة للدعوة الإسلامية في الحياة اليومية.

إذا نقرها الحاجة الملحة للاتصال في عالم الدعوة، وهذا يعني أن دور التواصل

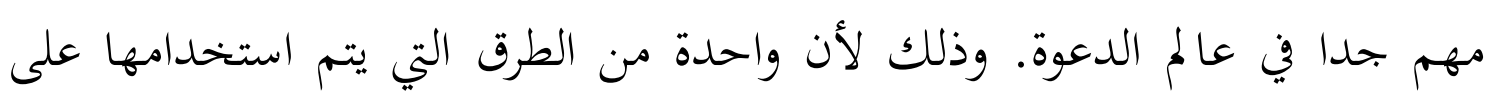

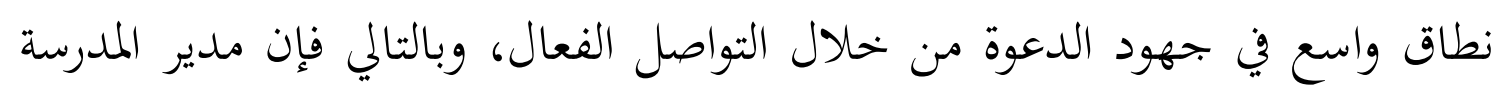


أو أهداف مهمتنا تماشيا مع ما كنا نتوقعه. وهذا هو، هناك تفاهم بين الدعاة أو

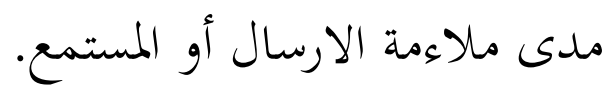
شخص ما في مهارات الاتصال تحديد مدى البصيرة التي يتمتع بها الشخص. الناس الذين معرفة واسعة ولها آفاق الاجتماعية تميل إلى أن تكون سهولة الاتصال، والتكيف، ونشرها. وعلى العكس من تلك التي الضيقة كل من المعرفة والخبرة

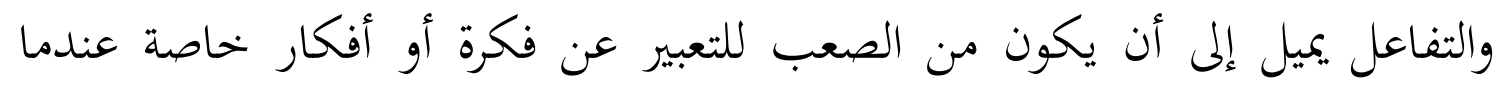
يكون التنشئة الاجتماعية مع الآخرين.

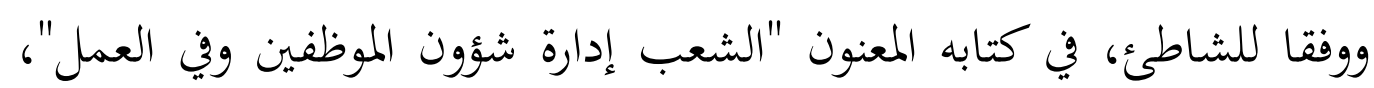

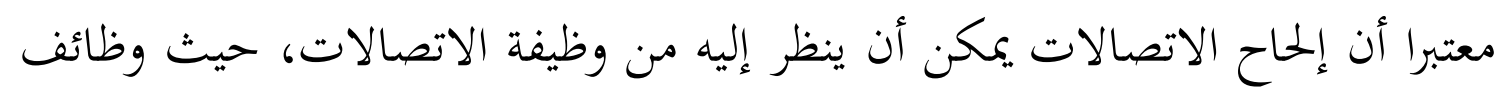

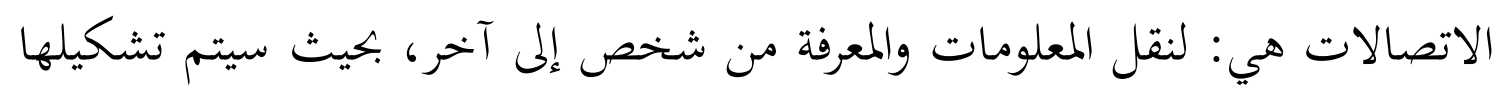

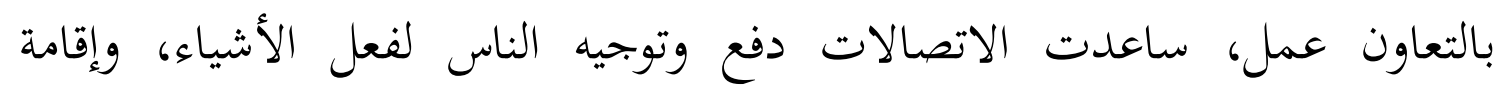
التواصل وبناء الثقة مع موقف يدعو، الإقناع، والتأثير على الأخلاق. 16

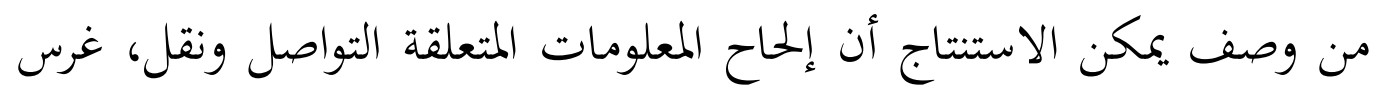

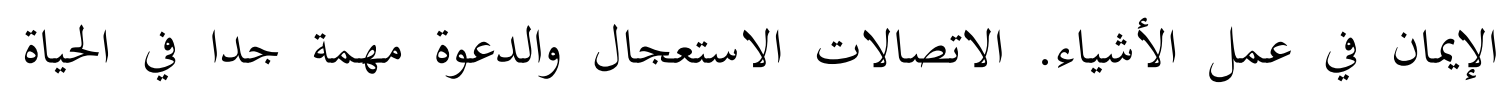

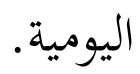

\section{طرق الدعوة في المجتمع المتعدد}

عندما نعيش ونتفاعل مع الناس من مختلف البلدان مع مختلف الثقافات، جميعا نتوق للسلام والسعادة. الإخلال الوحيد الذي يجعل الناس يشعرون ويتصرفون كما لو لو أغم أفضل من غيرهم.

والقرآن أشار إلى أن الأخوة الإسلامية تنفيذا وصيانة موقفا منفتحا الضروري،

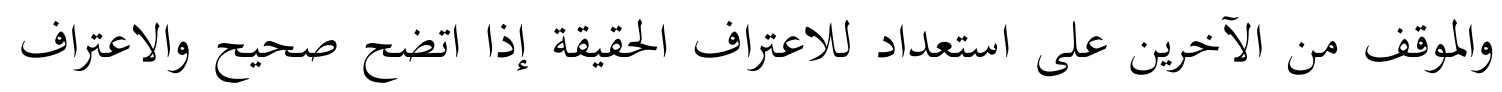


بالأخطاء نفسك إذا اتضح خطأ. ليس من السهل القيام به، لأنه يتطلب مستوى من الإخلاص والصدق مرتفعة للغاية، لذلك لا نشعر بأننا وحدنا تماما.

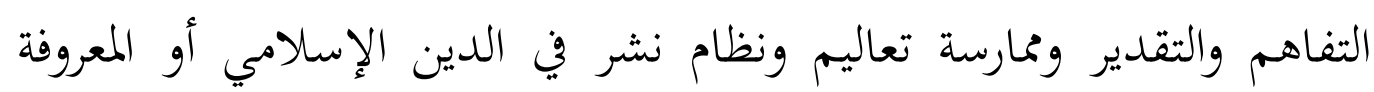

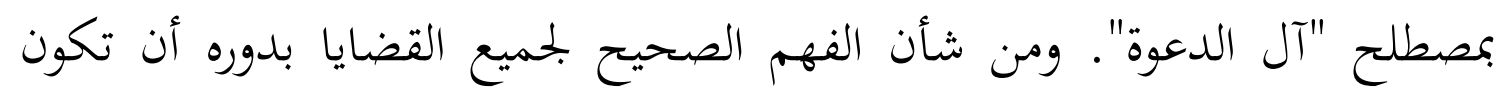

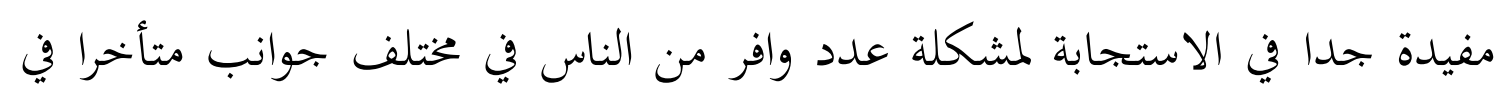
كثير من الأحيان مزمقة. تواجه المدعو مستويات ش متفاوتة من التعليم، والطبقات الاجتماعية،

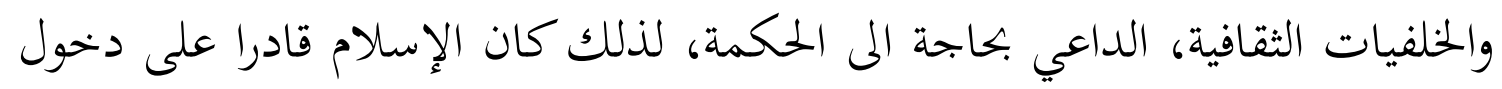

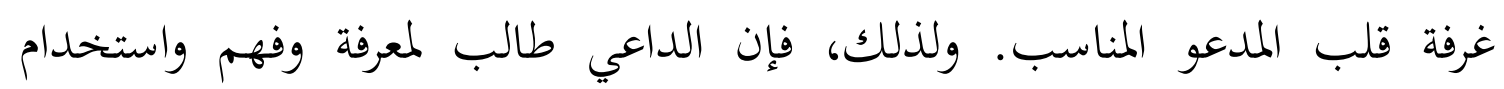
خلفيتهم، حتى أن الأفكار الواردة ينظر إليها على أهما شيء لمس قلبه. 17

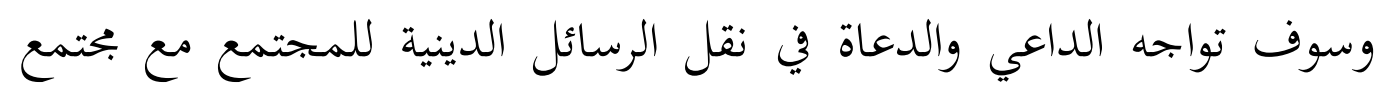

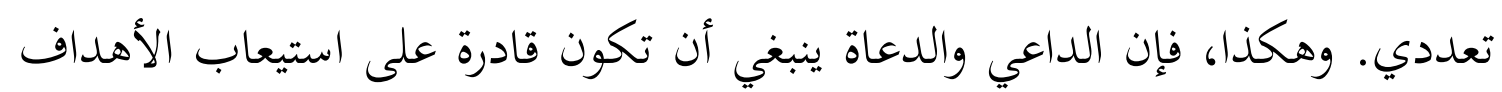

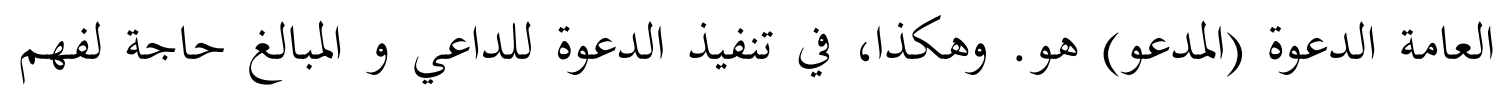
الهدف من الدعوة من مختلف الجوانب.

\section{أنماط الاتصالات والانتشار المدمج في الثدين الوئام}

القرآن سنح لنا أن في الحياة، والحياة البشرية، وتعديل مستمر للحياة وتيرة

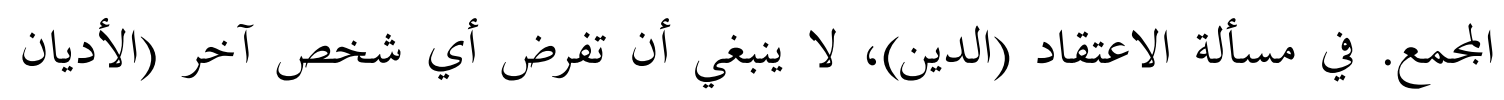

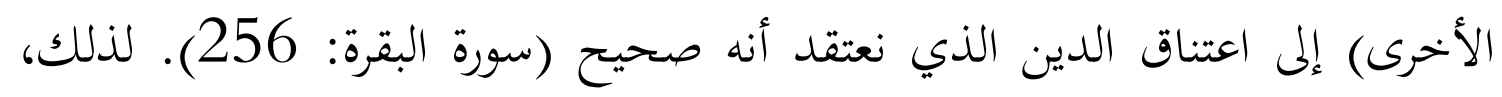

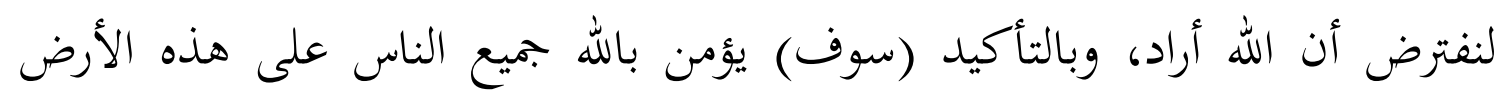

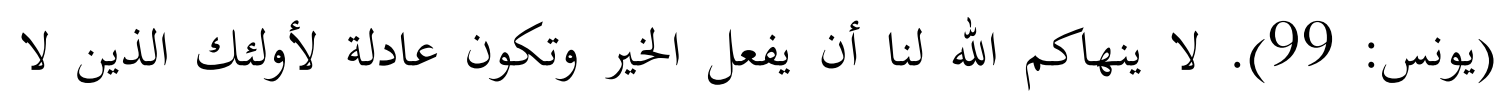
يقاتلوننا بسبب الدين ولا يطردوننا من أرضنا الممتحنة 8-9 لونم). 
لذلك، في بحتمع تعددي، والانسجام العيش معا يجب أن تكون محمية بشكل

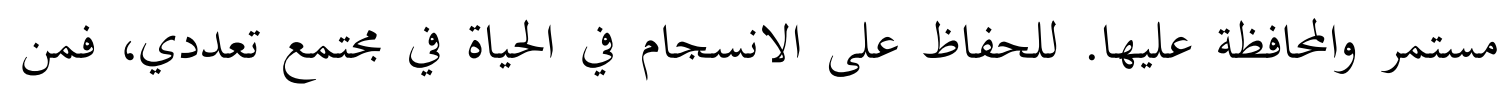
الضروري لبناء خطوات على النحو التالي:

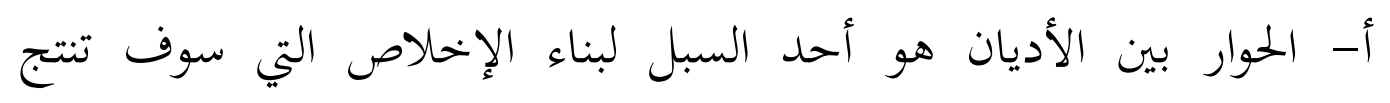

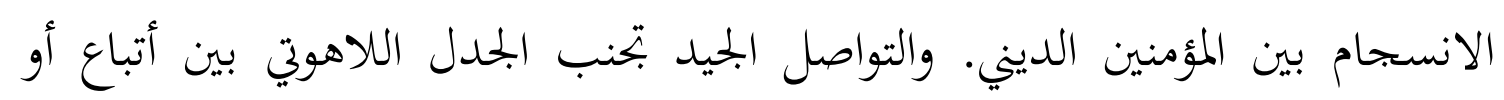

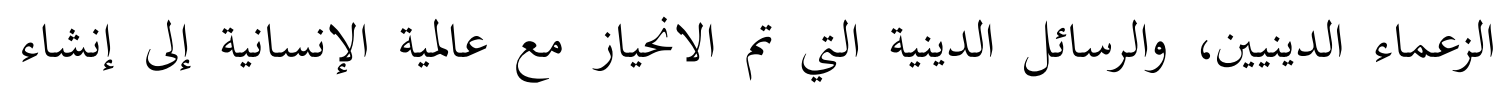

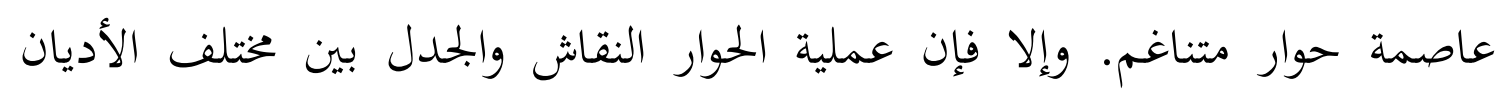
بجيث لا يوجد منتصر وخاسر.

ب. استعرض بعضها البعض، وهنا كل موضوع نظرت إلى وتلقي غيرها من

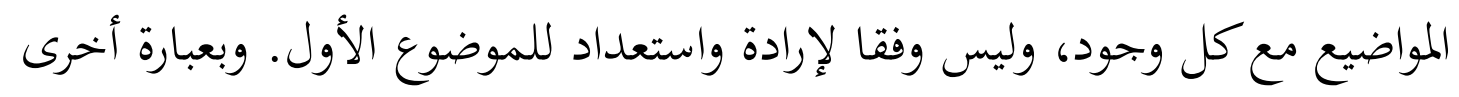

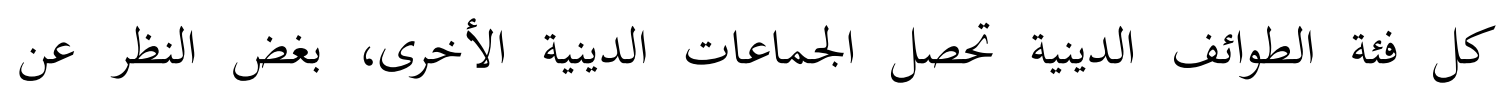
الاختلافات، ومزايا أو عيوب.

ج. الثقة المتبادلة هي حقيقة وبيان القبول المتبادل. والعقبة الرئيسية في الحفاظ

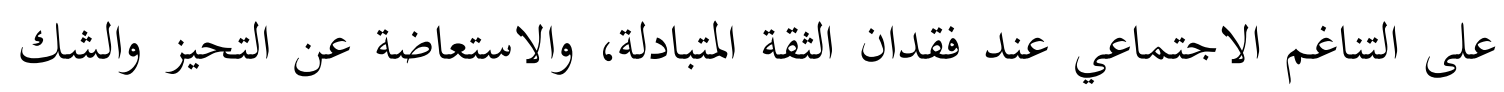

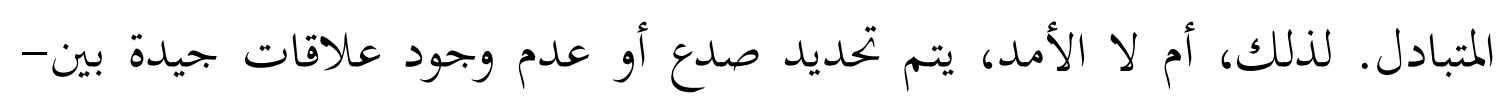

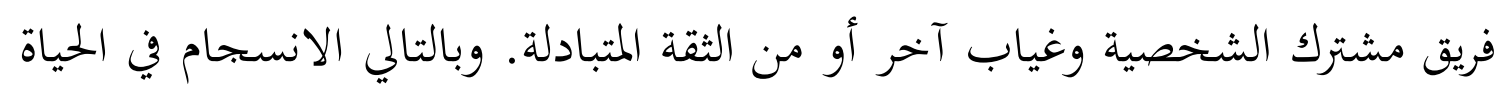

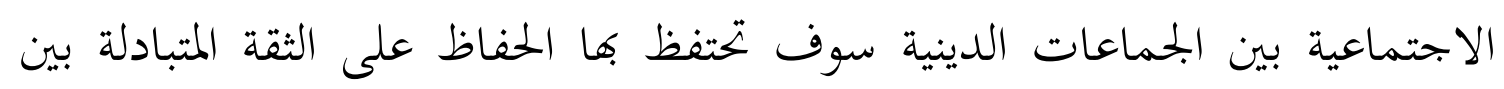
طائفة إلى طائفة دينية أخرى. د. مبدأ التفكير الإيجابي. وئام وظيفي بين الأديان كمنظم للعلاقات الخارجية

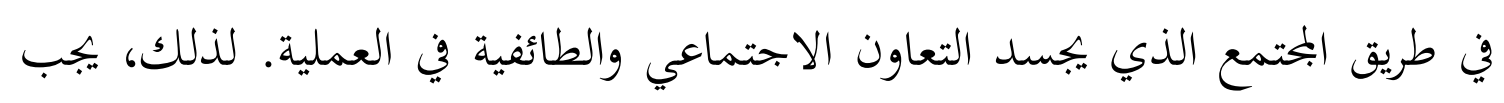

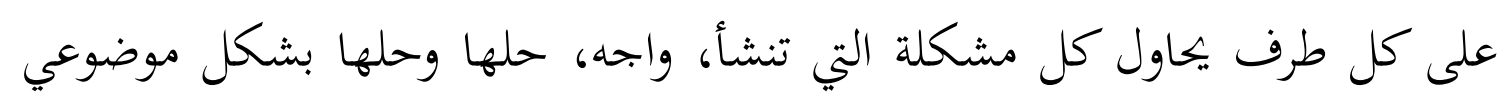
التفكير الإيجابي. 
الوعي واسعة من تعدد مناحي الحياة المختلفة أن الدين سوف يسبب المواقف

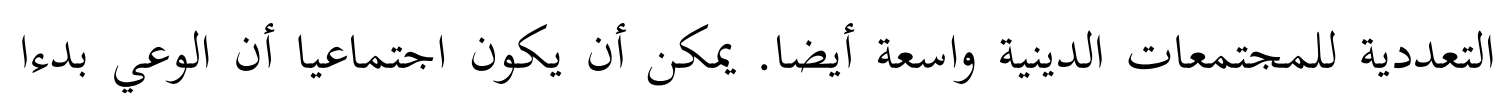

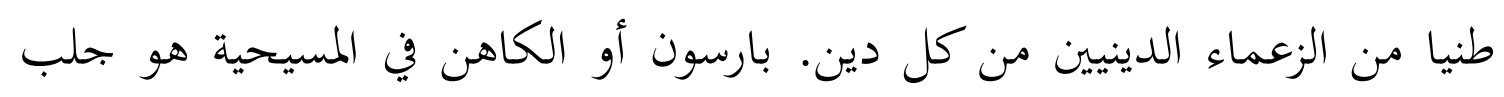

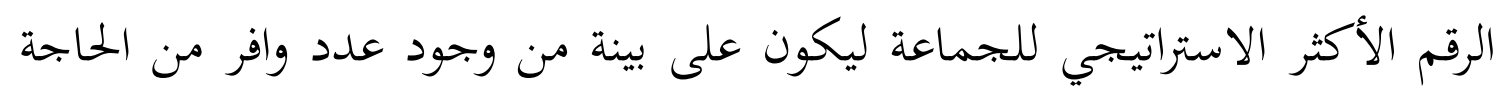

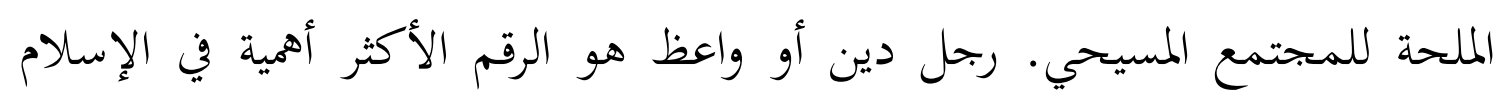

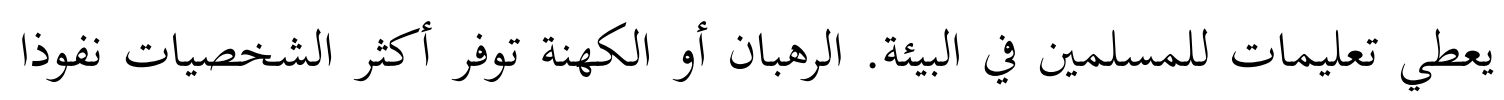
شغف التعددية لالبوذية والهندوسية. 19

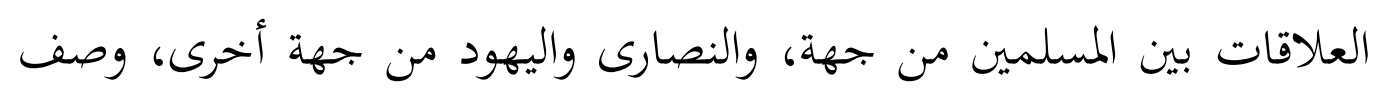

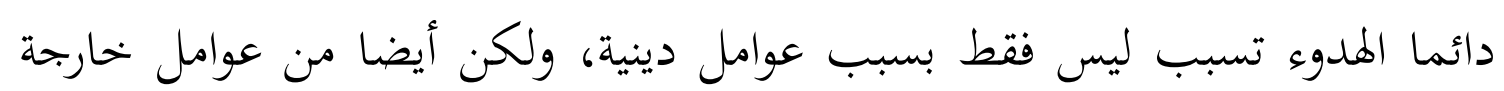
عن الدين أساسا العوامل وعوامل اقتصادية وسياسية. 20

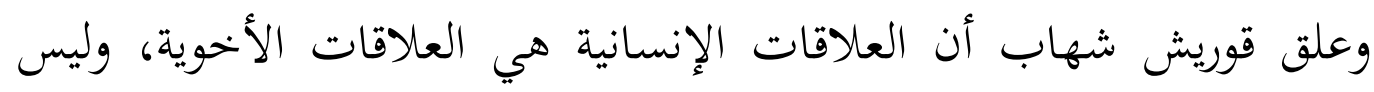

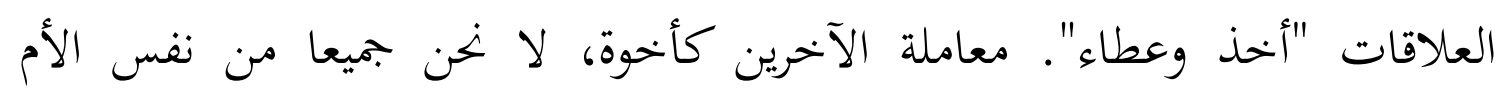

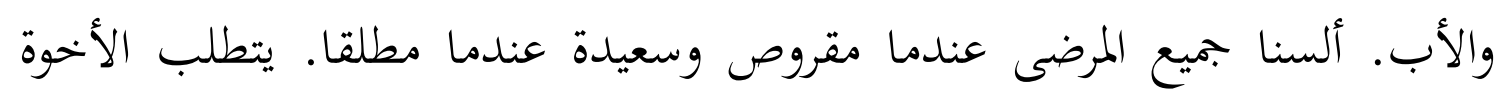

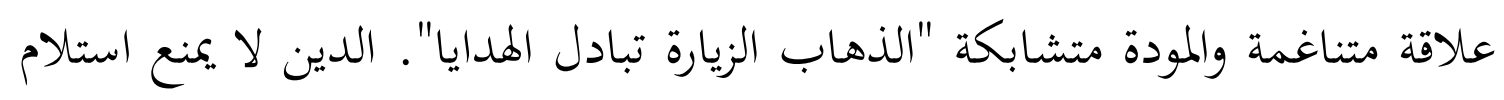

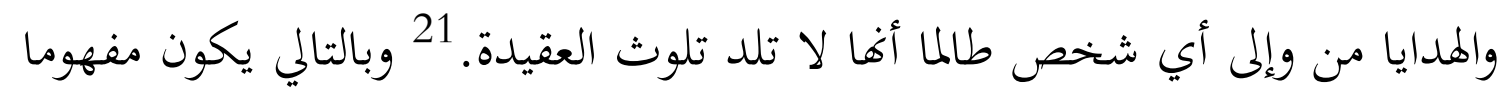

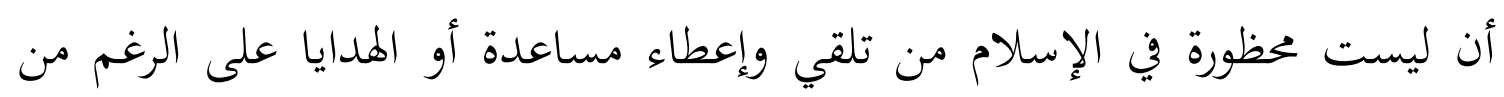
الديانات أو المعتقدات المختلفة. "أنا عند تسليمها الدعوة المادية التي تجعل من الممكن تحديد كانت المعات تتواصل

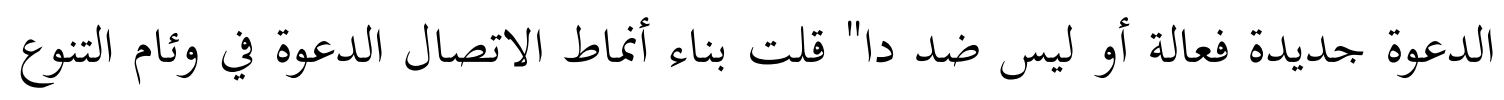

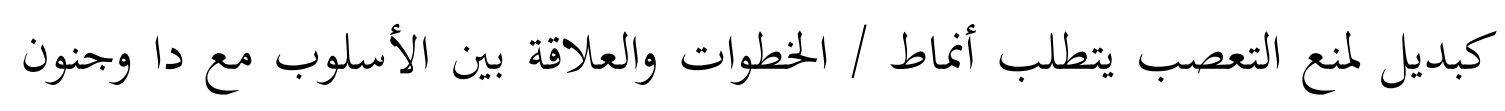

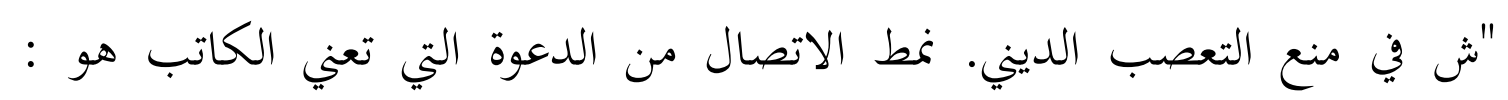
أساليب الدعوة في بحتمع تعددي. 
عندما نعيش والثفاعل مع الناس من مختلف البلدان مع مختلف الثقافات، جميعا نتوق للسلام والسعادة. الإخلال الوحيد الذي يجعل الناس يشعرون ويتصرفون كما لو أفم أفضل من غيرهم.

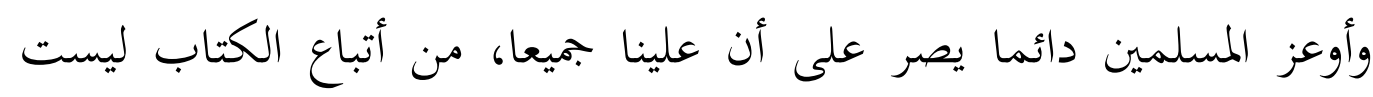

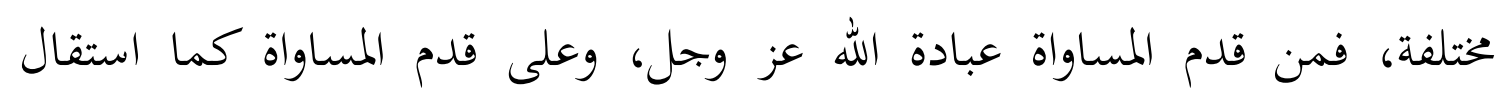

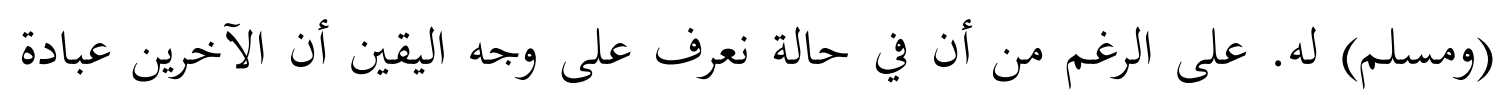

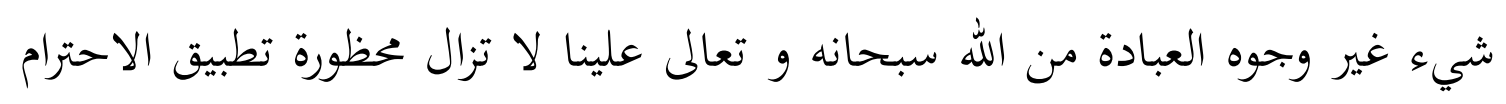

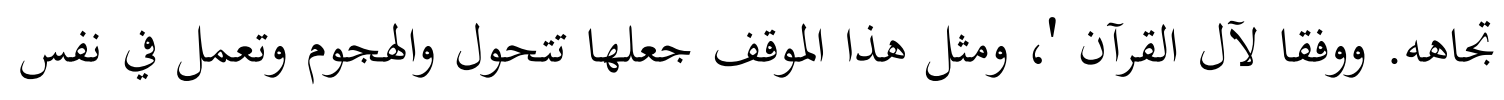

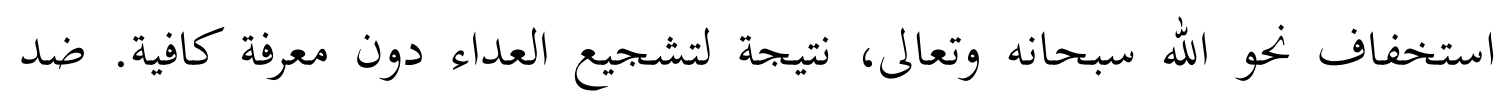

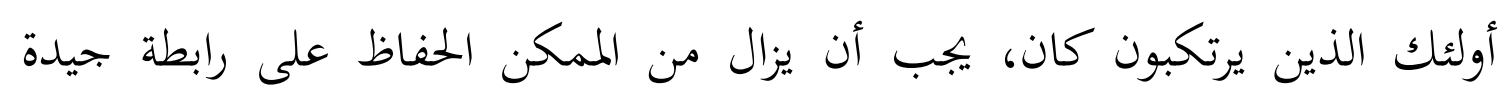

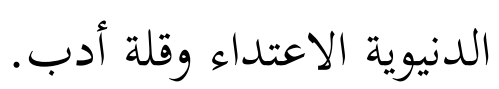

كل الدول متساوية ومتوازية في النقص بهم. ومع ذلك، لديهم ميزة أخرى الند

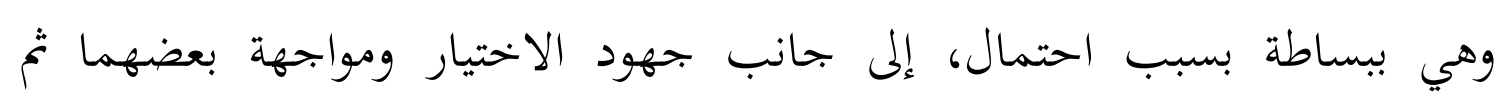

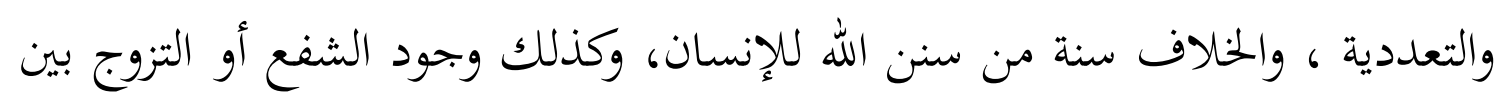
الخلق.22

إن الصحابة والمسلمين عامة من وقت إلى أخر قاموا بتطبيق المبادئ والقيم

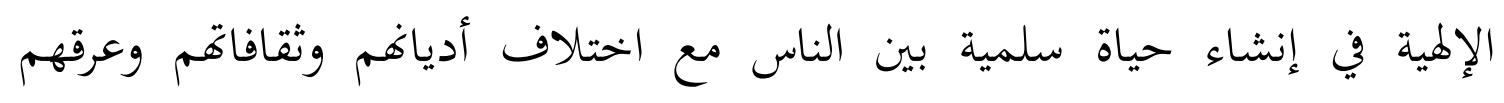

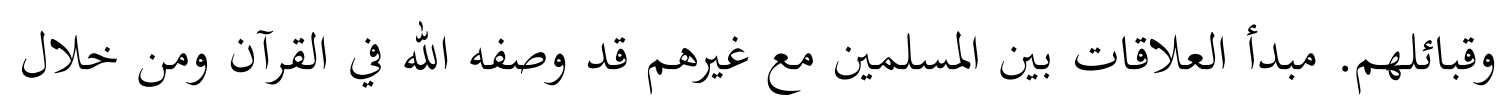

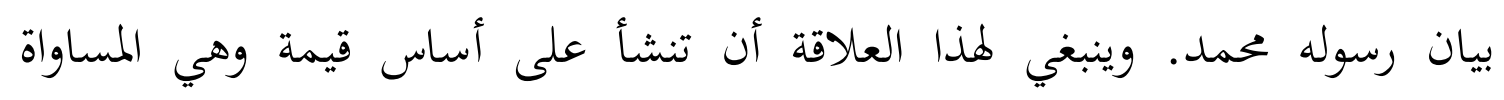

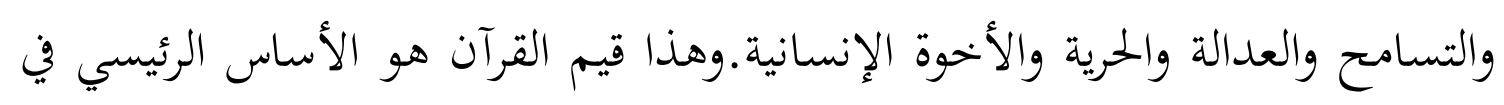
إنشاء العلاقات الإنسانية المختلفة في العرق والدين واللغة والثنافة. 
الصورة الحقيقية مختلفة على الساحة تشير إلى أن التسامح في مواجهة التعددية

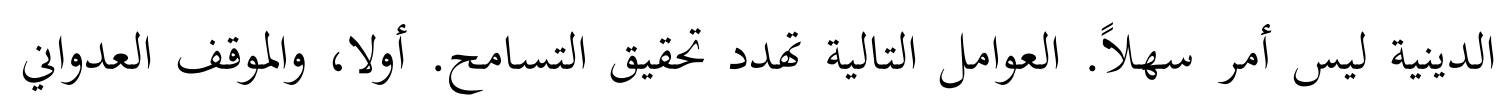

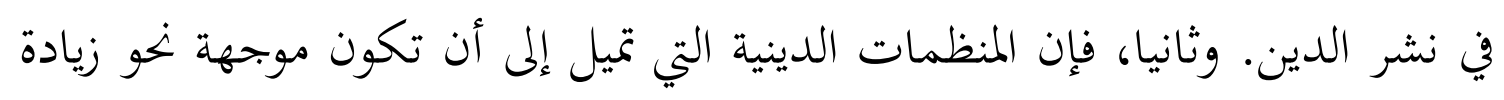

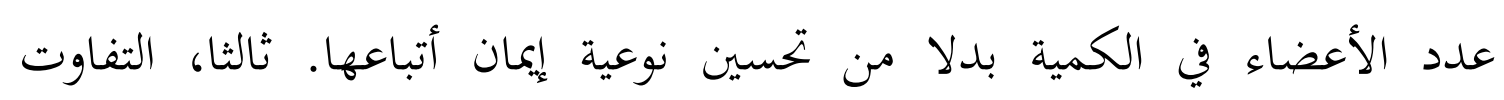

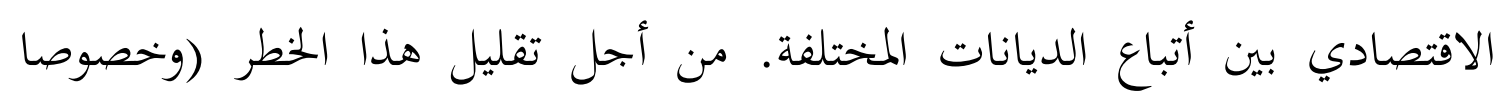

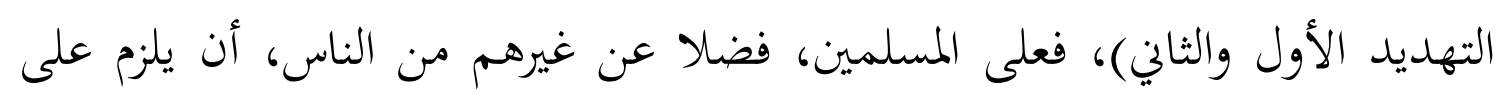
تنظيم أنشطة نشر دينهم أو الدعوة إليه بطرق مناسبة ممتازة.

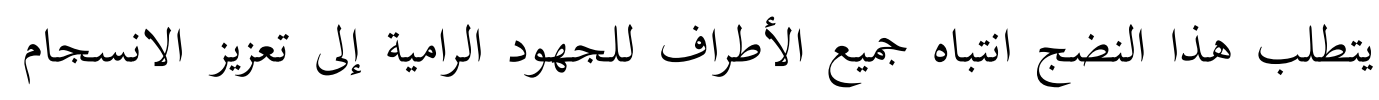

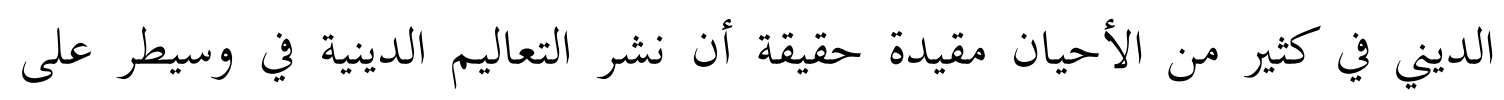

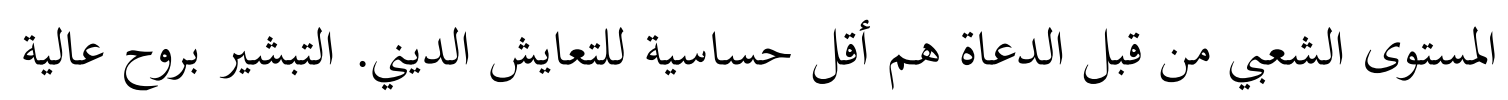
من النشطاء الدعوية في كثير من الأحيان ملوثة في تشويهه لصورة دين لآخرين.

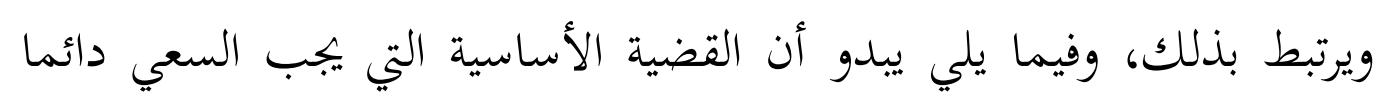

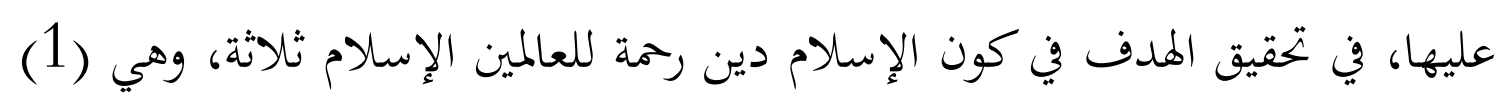

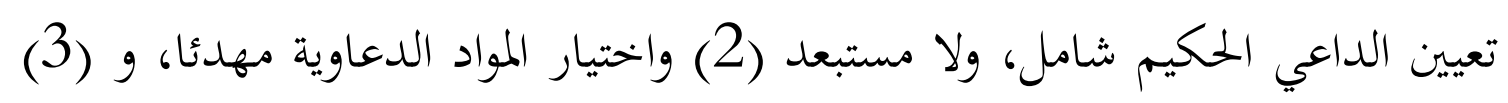

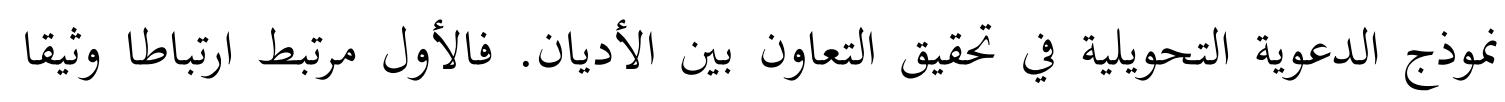

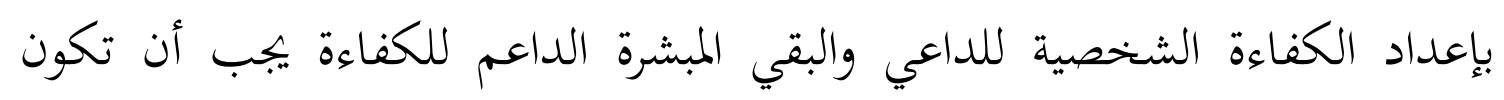
شغلا للواعظ أو للخطيب.

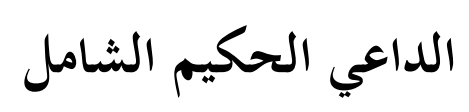

فليس من واجب كل مسلم تنفيذ تعاليم دينه فحسب، ولكن يجب عليه أيضا

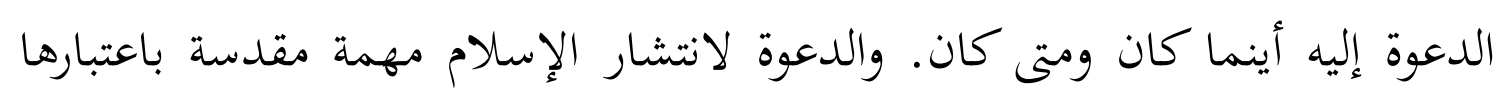

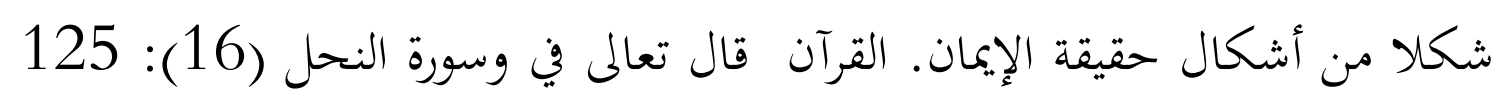

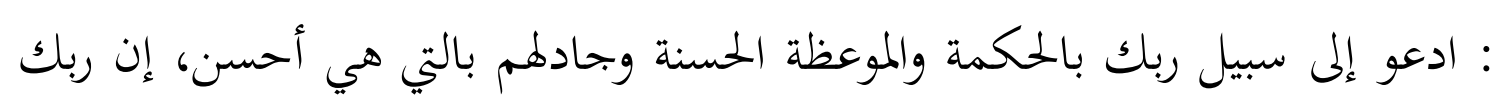


هو أعلم بمن ضل عن سبيله وهو أعلم بالمهتدين. وكذلك الأحاديث الكثيرة التي

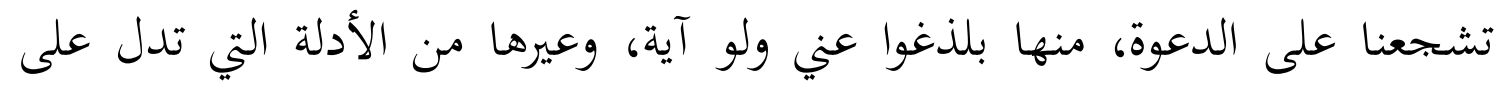

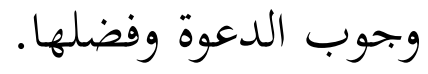

ومن الأدلة السابقة، يجب علينا الانتباه على نفطة مهمة، وهي أن الدعوة لا

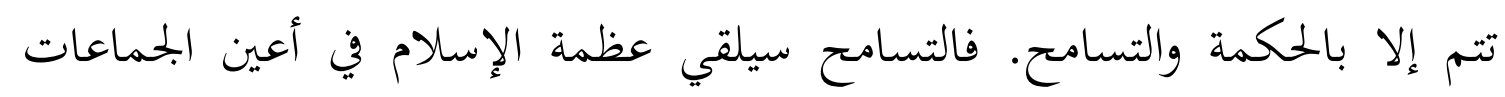

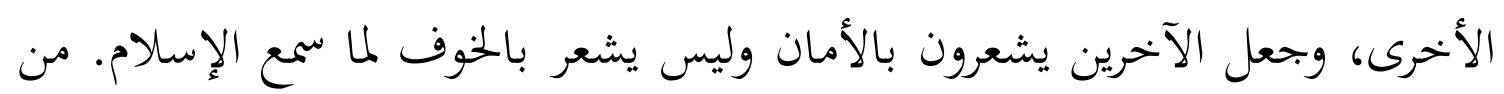

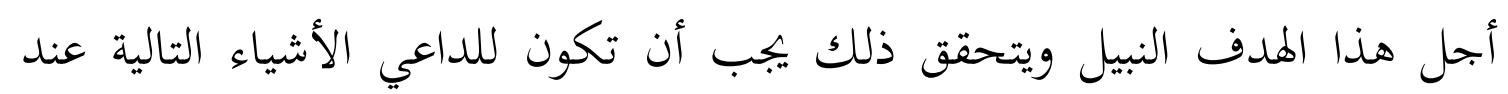
قيامه بالدعوة في المجتمع التعددي. أولا، يكون على الداعي افعم على عدم التجانس المدعوين الذين يواجهرهم.

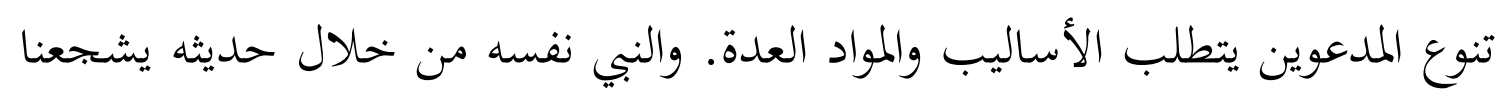
على تقديم المشورة والمعلومات للآخرين على مستوى عقولمم.

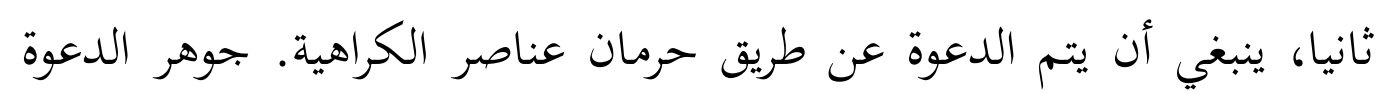

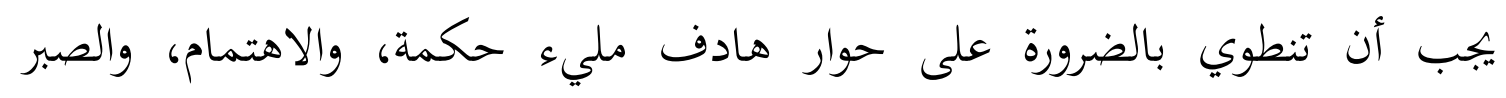

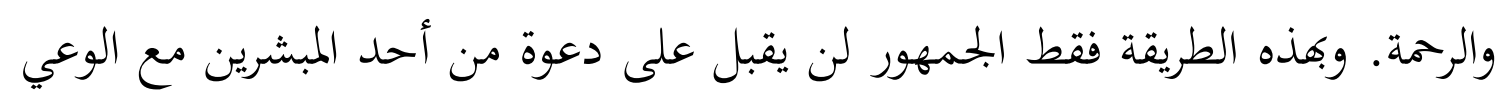

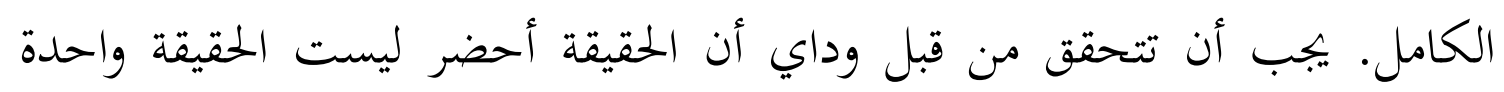

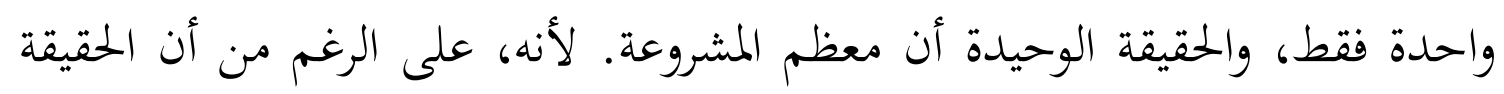

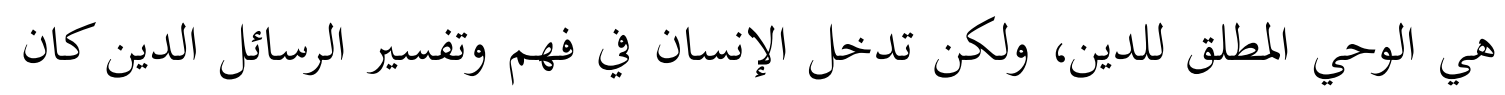

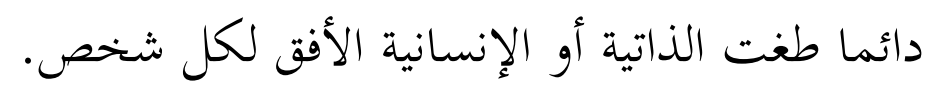

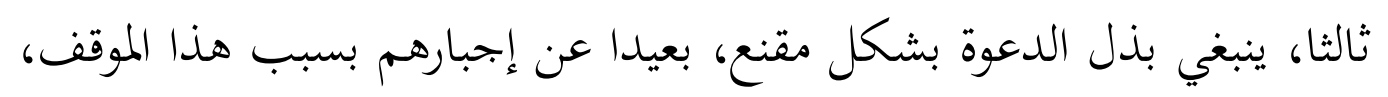

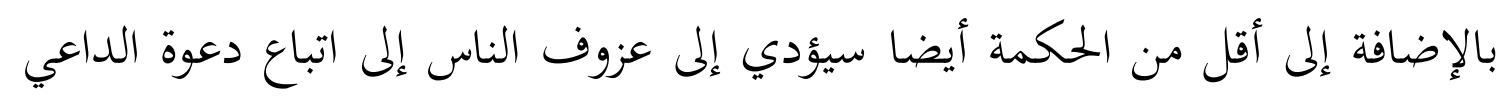

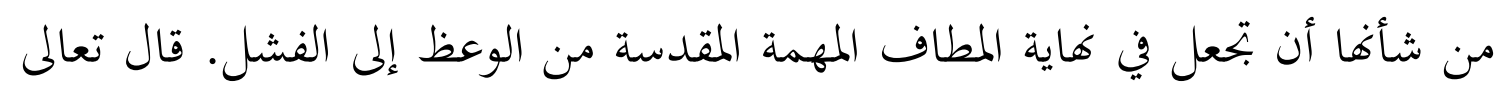


: قل الحق من ربكم فمن شاء فليؤمن ومن شاء فاليكفر، وقال تعالى : لا أكراه في الدين، فقد تبين الرشد من الغي. رابعا، تجنب الأفكار والمواقف بإهانة وتشويه سمعة الدين أو الكفر. قال الله الله

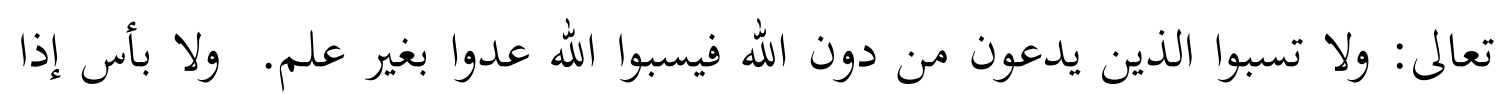

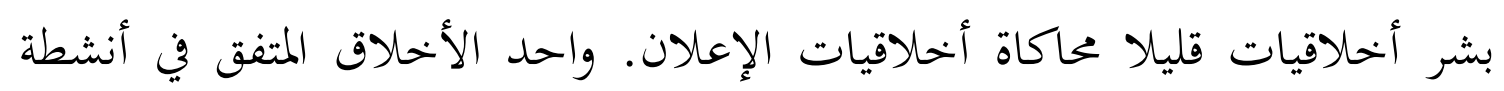

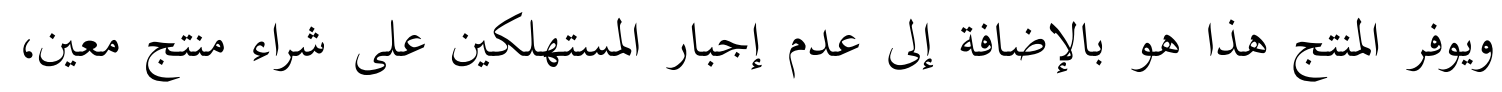

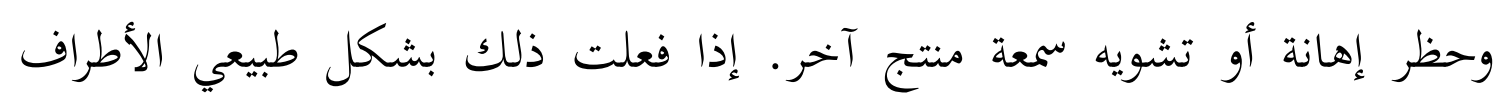
المتضررة واستدعاء والاحتجاجات ويمكن أن يؤدي إلى شكوى التشهير. خامسا، تحمل الخنافات والابتعاد عن التطرف في الموقف من الدات الدين. المبدأ

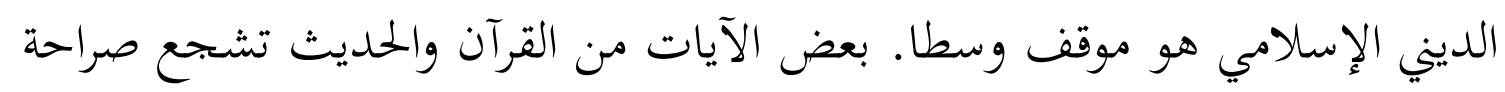

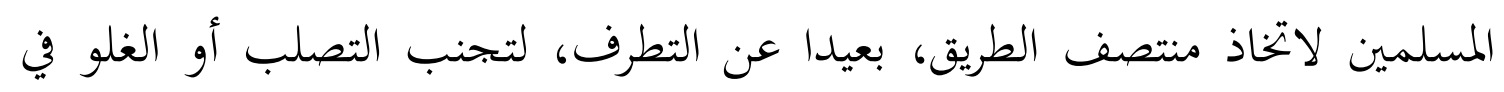

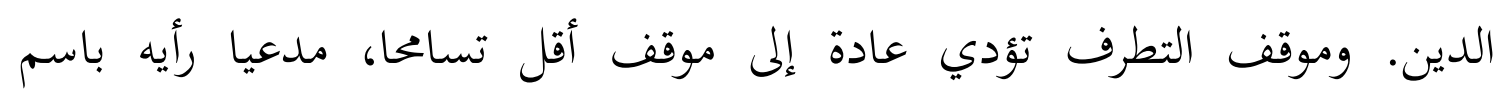

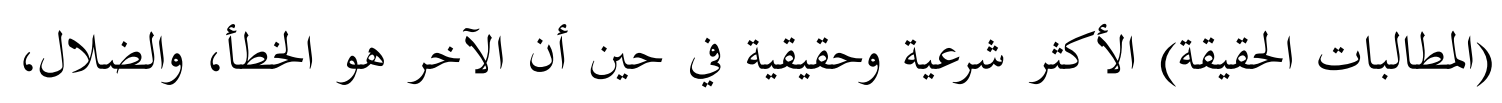
ومحاولة "آه (الأرثوذكس). وقال علوي شهاب في تصريح قول أبي إسحاق الشاتبي

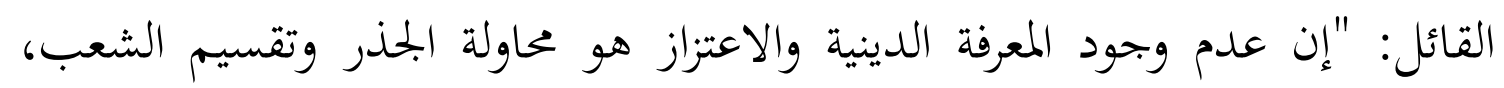
ويمكن أن يؤدي في غاية المطاف إلى الصراع الداخلي والاتحاه الفتنة ببطء. 23

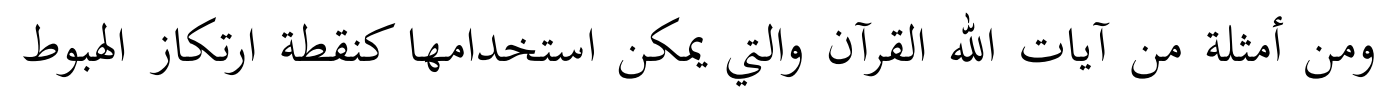

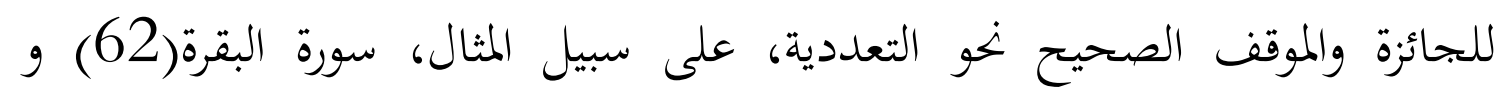

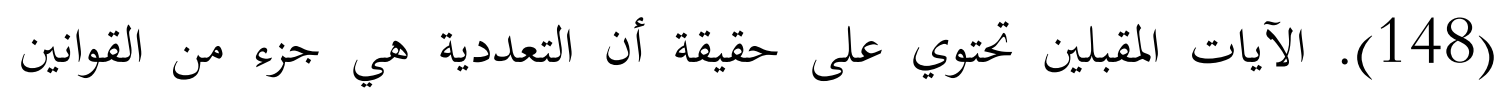

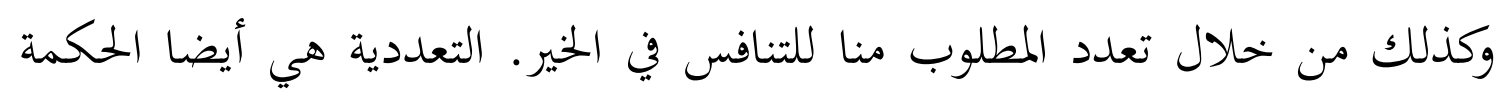
السائدة الله في التاريخ في سورة الروم22 والبقرة تعدد لمطل 213. 
وهذا يعني أن عدد وافر من هذا الواقع هي رغبة الله نفسه، لأنه إذا شاء الله، وبالتأكيد هو الذي خلق البشر في بحتمع واحد. وتتكرر مثل هذه الفكرة في أماكن كثيرة في القرآن "ومع تأكيدات مختلفة مثل اختبار الجودة لإدارة عبده فيده (المائدة : 48)؛ محذرا من أن يحلو لهم أن نختلف(هود : 118)؛ مع إعطاء تعليمات لأوليك إنك

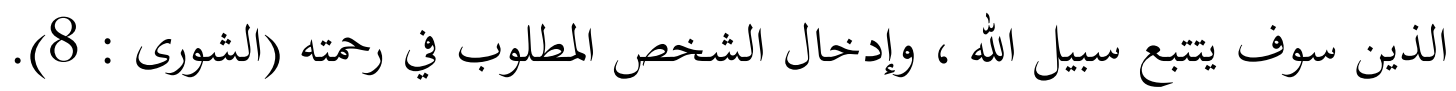
والقرآن أيضا يدرس صراحة على أن الأساس البشرية هي فريدة (سورة البقرة:

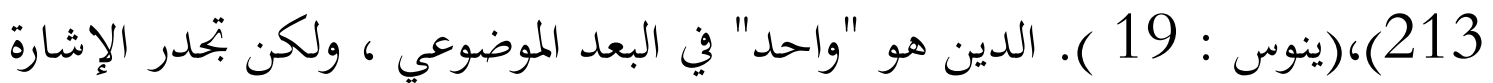

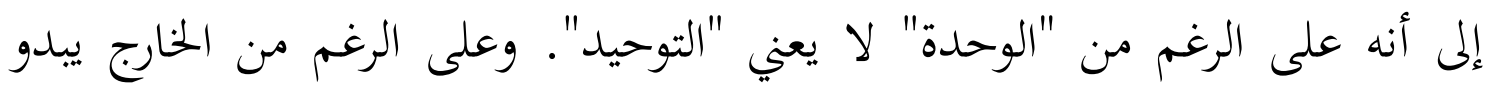

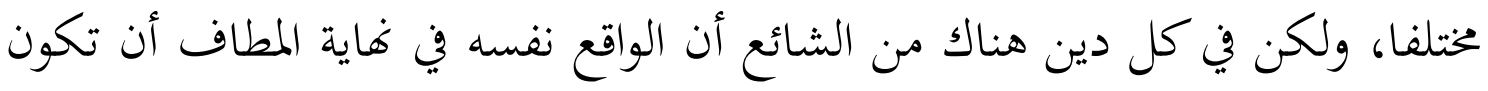
النهاية من كل دين. بسبب تشابه هذا أن القرآن "دعوة جميع رجال الدين لإيجاد أرضية مشتركة، أو المعروف باسم كلمة سواء. 24 "قل يا أهل الكتاب تعالوا على كلمة سواء بينا وبينكم ألا نعبد غلا الله ولا الا نشرك به شيئا ولا يتخذ بعضتا بعضاً اربابا من دون الله" لهابل

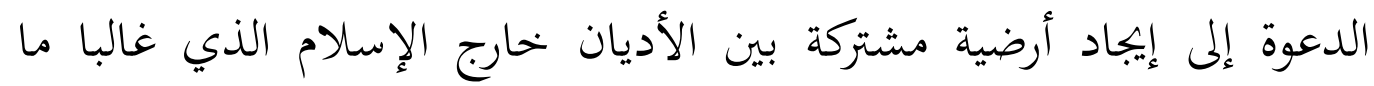

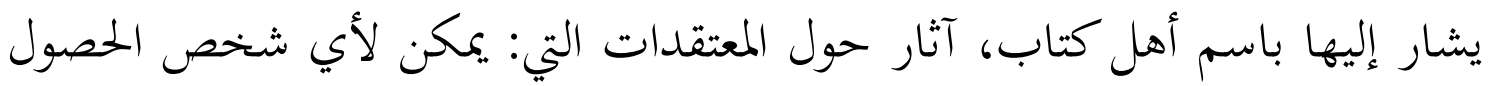

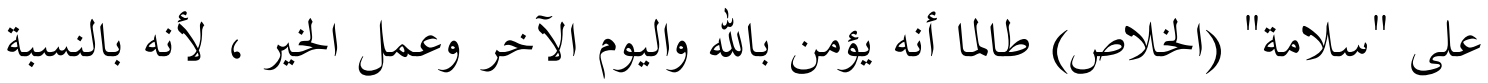

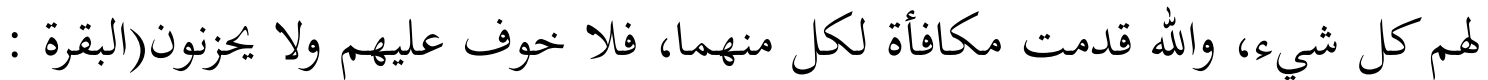
62) والفقرة مشابهة لهذه (المائدة : 59).

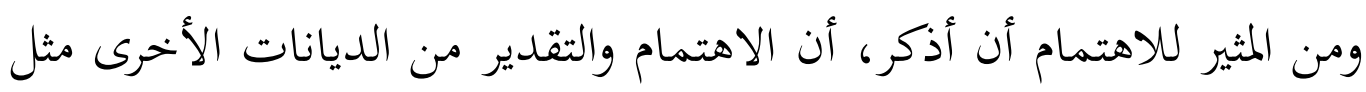
الإسلام سيكون فوق جزء حقيقي وأيضا متطلبات كمال إيمان مسلم. هذا يعني أنه

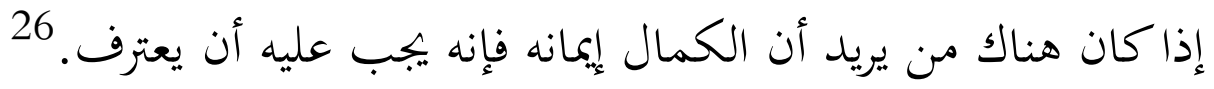


واحترام الأديان الأخرى ليس من المستغرب أن مثل هذا التسامح عالية يصبح

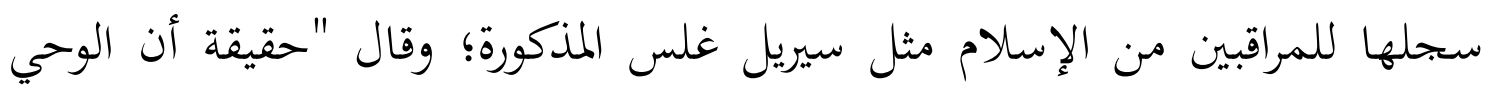
(الإسلام) يذكر بآيات أخرى خجل يعد حدثا كبيرا في تاريخ الأديان. 27

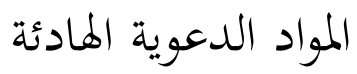
بعد هذه الكفاءة (أو بعبارة أخرى أخلاقيات الأساسية) وفيما يلي استيعاب

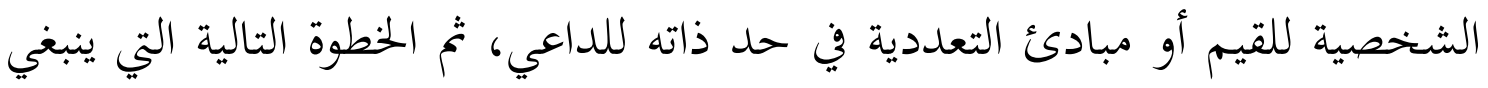
النظر فيها من قبل الداعي إن كان اختيار المواد من الدعوة. اختيار المواد الدعوية في السؤال هنا هو مدى احتمال تعزيز الرسائل الدينية التي تعطي البرودة وبتنب استفزاز

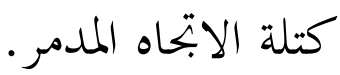
لتحديد المواد الدعاوية على النحو المذكور سابقاً، وبالإضافة إلى ذلك يتم

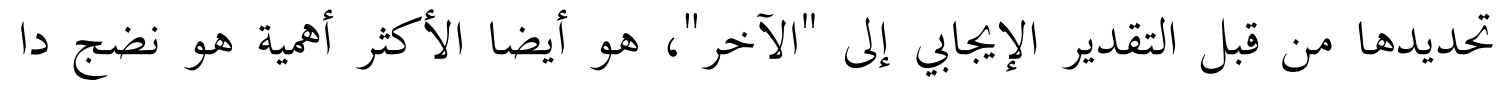

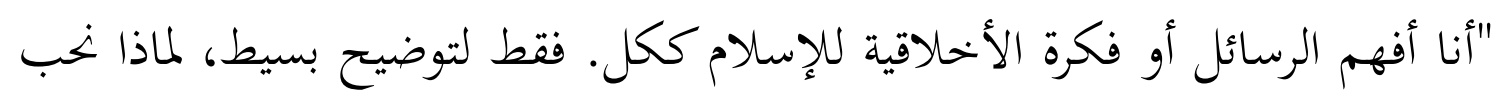

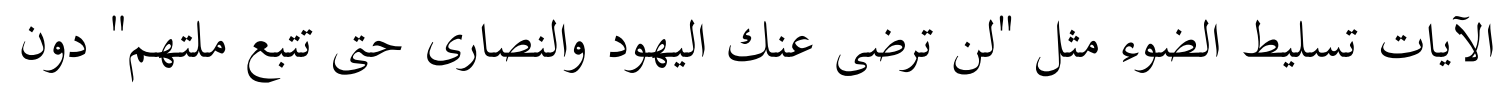

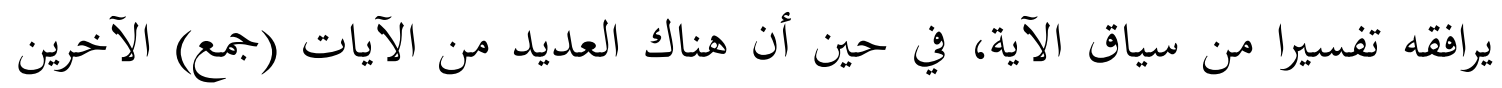

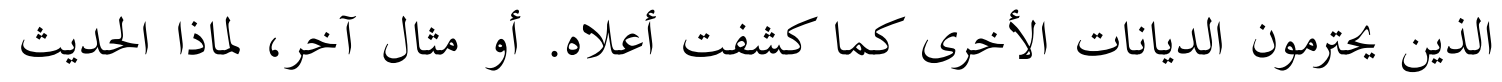

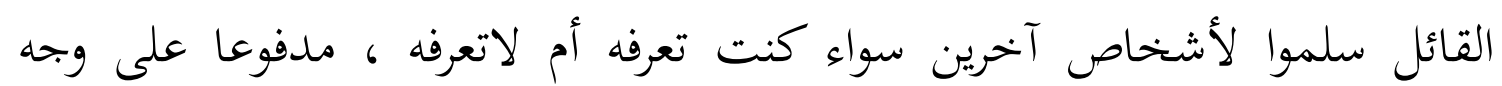

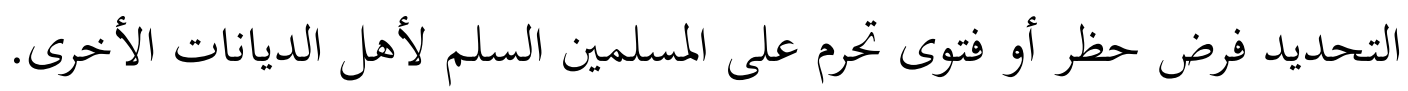

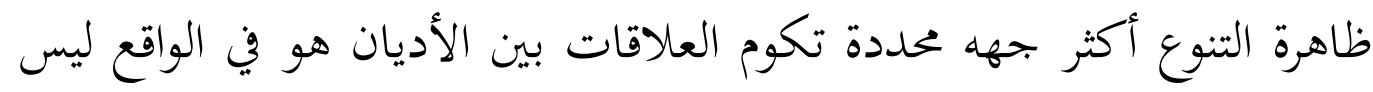
فقط بسبب اختيار الداعي لن يهم الوعظ وحدها، ولكن أيضا بسبب عوامل أخرى.

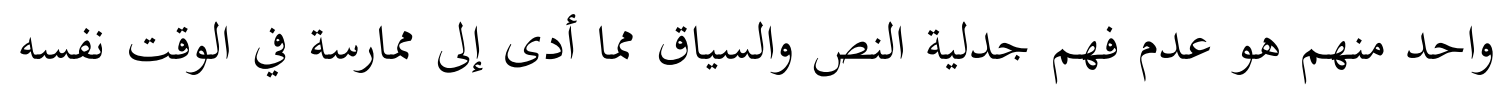

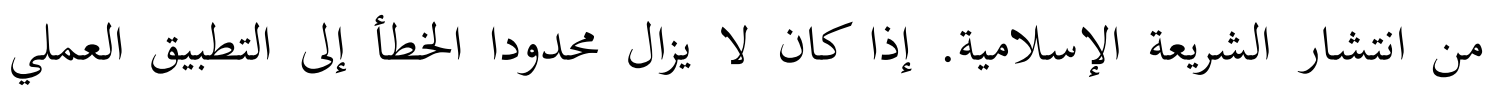
الفردي بالتأكيد ليست مشكلة. المسألة تصبح معقدة عندما يتم الإبلاغ المفاهيم 
الخاطئة وبشر لعامة الجمهور. والسبب هو أن القانون واضح والإسلامية التي هي غنية

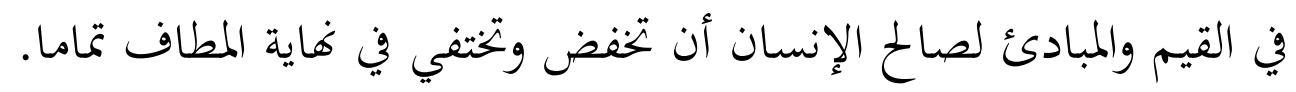

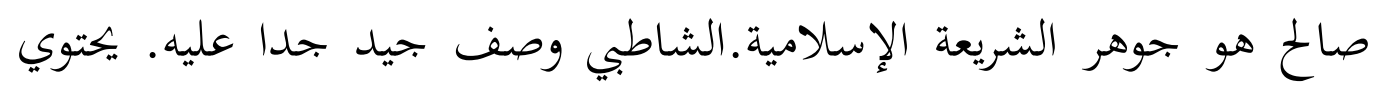

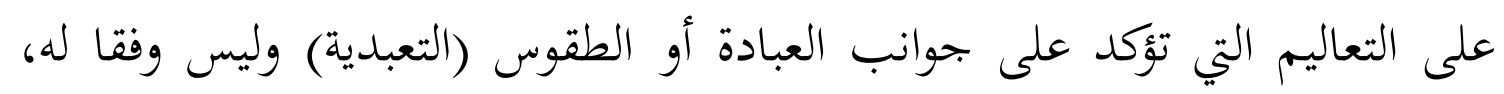
ولكن أيضا تحقيق الفائدة للبشر. 28

الخحلاصة

في الحقيقة، إن إندونيسيا هي البلد الذي لديه بحموعة متنوعة من الدين

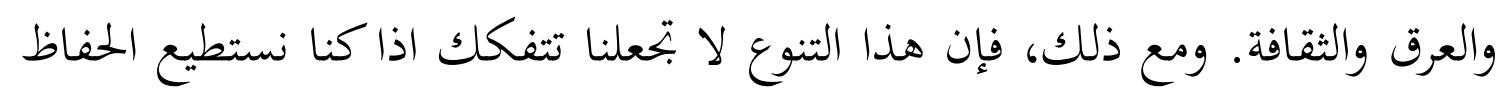

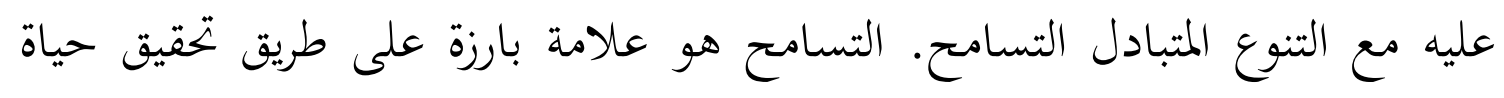

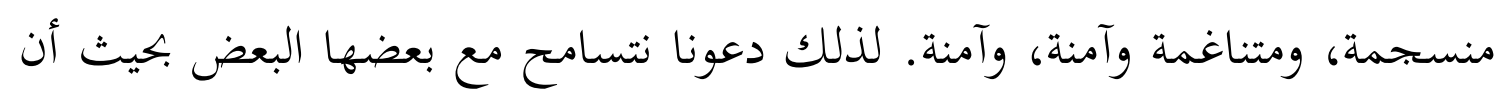

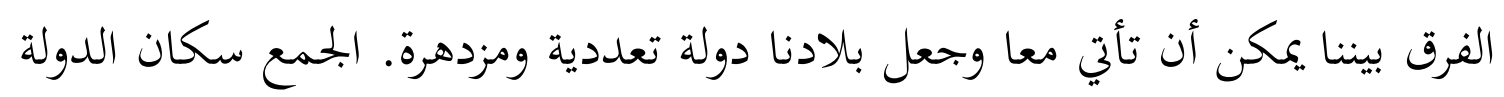

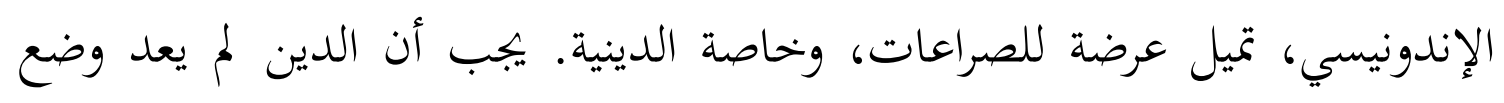

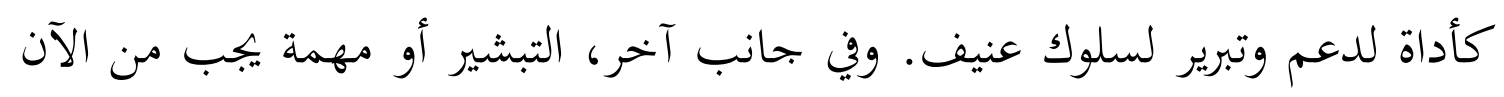

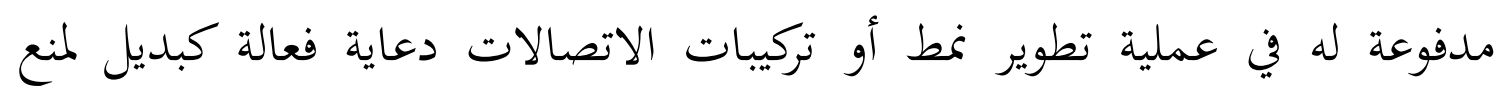

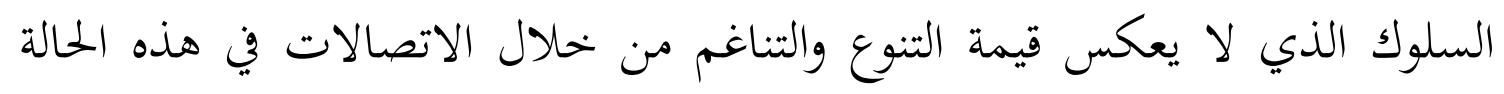

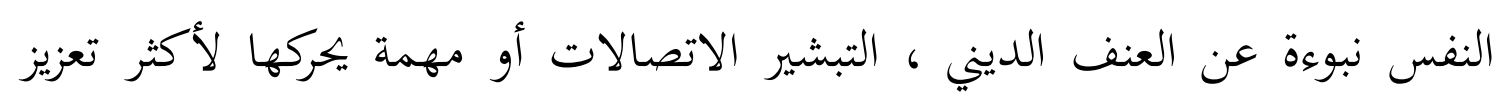

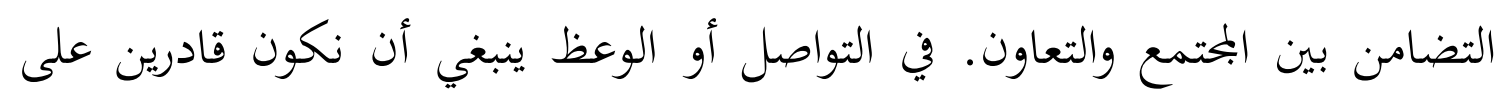

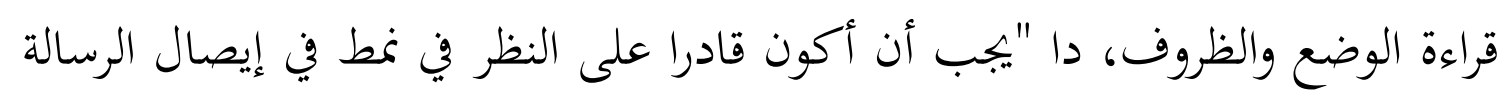

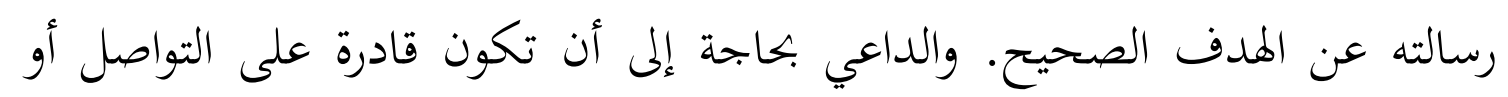

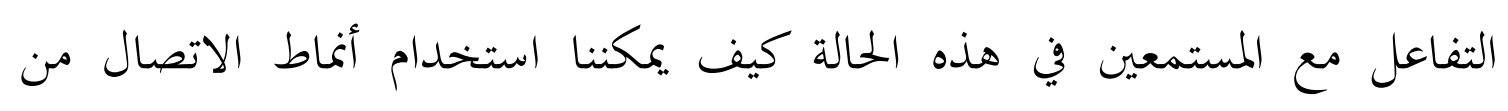

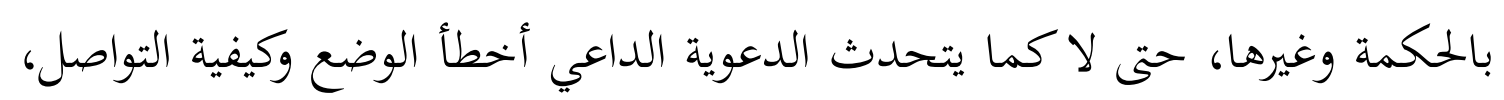

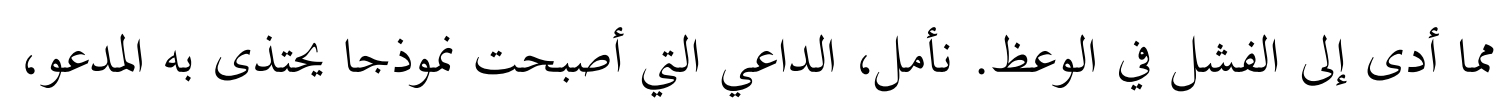


وقادرة على نقل رسالة من الوعظ جيد والحق دون مدعيا أن بحموعة أخرى، لذلك سوف يتحقق ذلك منع التعصب والتسامح الديني في هذا البلد الحبيب.

الإمام الحافظ أبو الفضل أحمد بن علي محمد بن حجر العسقلاني المصري رحمه الله (852-773 هـ) فتح الباري في شرح صحيح البحاري، بيروت، دار الكتب العلمية، الصفحة 247 ابن فارس بن زكريا، مقايس اللغة، المكتبة الشاملة، النوع الثاني تويبي، أرنولد (1947) Dorothea Grace Somervell. A Failure of Self-Determination Study of History: Abridgment of Volumes I - VI. New York, NY: Oxford University .Press. p. 300. ISBN 0-19-505081-9 شمس المنير أمين، Ilmu Dakwah، (جاكرتا، Amzah) الصفحة 55 تويبي، Surviving the Future، نوي يورك 7 (London: Oxford University Press, 1973) الصفحة 38 بودي رجب، Jurnal Prisma ‘Suatu Tinjauan Umum : Pluralisme Masyarakat Indonesia جاكرتا، الرقم 6، اليوني 1996، الصفحة 23 الوزارة التربية والحضارية، Kamus Besar Bahasa Indonesia (جاكرتا، Balai Pustaka، 691 1993) الصفحة

شمس المنير أمين، Ilmu Dakwah، (جاكرتا، Amzah) الصفحة XViii أحمد أنس، Paradigma Dakwah Kontemporer) (سيمارنج، Walisongo Press IAIN 114 Walisongo الشهيد سيد قطب، تفسير في ظلال القرآن، المترجم، أسعد ياسين، (جاكرتا، Gema 128 Insani Press 
أحمد أنس، Paradigma Dakwah Kontemporer، (سيمارنج، Walisongo Press IAIN 37 Walisongo

Oxford: University Printing ( Oxford Advanced Learner’s Dictionary ،ورنبي أس،

.67 (House, 1995

بودي منور رحن في علوي شهاب، Islam Inklusif، (جاكرتا، Taraju Press, 2005 (ج) أديب إسحاق، الأفغاني، 1993، أضوء على التعصب، بيروت، دار أمواج، الطبعة الأولى

أحمد المخزبخي، 1987، العدل والتسامحالإسلامي، القاهرة، مؤسسة الأهرم، 54 الصفحة

أحمد ويرسون منور، 1997، Kamus al-Munawwir Arab- Indonesia Terlengkap، Pustaka Progresif ،Surabaya الحسين محمد الراغب الأصفهان، 1997، معجم المفردات لألفاظ القرآن، بيروت، دار الكتب العلمية، الطبعة الأولى، الصفحة 89 حسنين توفيق إبراهيم، 1998، النظام السياسي والإخوان المسلمون في مصر، من التسامح إلى المواجهة، يروت، دار الطليعة، الطبعة الأولى، الصفحة 107 إنعام حمود حمد، التسامح في الإسلام وأثره في درء التعصب والإرهاب القاهرة، جامعة القاهرة، الصفحة 64 حمد عبد القادر أبة فارس، 1994، التعددية السياسية في ظلال الدولة الإسلامية، بيروت، مؤسسة الريان، الطبعة الأولى، الصفحة 105 محمد الغزالي، 1993، التعصب والتسامح بين المسيحية والإسالام، القاهرة، دار التوزيع والنشر الإسالمية، الطبعة الثانية، الصفحة 126. 
محمود إمارة، 1997، التعددية، الرؤية الإسلامية والتعددية الغربية، مصر، دار النهضة، الصفحة 205

فريش شهاب، Wawasam Al-Qur'an، باندونج، mizan، الطبعة الثالثة يوسف القرضاوي، 2000، العقليات الدينية والحل الإسلامي، بيروت، مؤسسة الرسالة، الطبعة الأولى، الصفحة 97 أنس أحمد، Paradigma Dakwah Kontemporer 'Prikasi Teoiritis dan Praktis Dakwah PT. Pustaka Rizki Putra ‘sebagai Solusi Problematika Kekinian علي عزيز، محمد، 2004، Kencana، إكر 2llmu Dakwah،

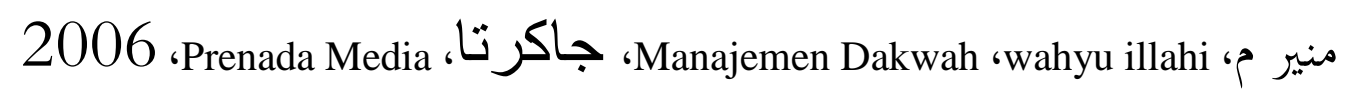
الراغب الأصفهان (أبو القاسم الحسين بن محمد بن المفضل) (502هـ/1108 م)، 1997، معجم المفردات لألفاظ القرآن، بيروت، دار الكتب المصرية، 1364 